\title{
The Language of Offer and Acceptance: Speech Acts and the Question of Intent
}

Language and law interact in a number of ways, the most obvious of which is that laws are expressed in language. Lawyers often look at language to determine the meaning of specific statutes. In such a relatively artificial context, words are chosen and interpreted with unusual care. But elsewhere, the law must interpret utterances of a more spontaneous sort, where the actual meaning of a word or phrase is not always found in a standard dictionary and a grammar text. This especially holds true when the law must give legal effect to the utterances of private individuals. The interpretation of private utterances is an important part of contract law, particularly in the area of offer and acceptance. Courts attempt to discover whether the parties have assented to an agreement by examining their words and deeds. There is no standard verbal formula or prescribed conduct which invariably signifies assent. On the contrary, the case law suggests a great variety of ways to reach agreement.

This Comment will elaborate a theory concerning the elusive relationship between words and their legal effect. It will explain why use of the word "offer" does not necessarily denote a legally binding offer. Conversely, it may explaim why an offer need not contain the word "offer" or a similar expression. The analysis will be based on speech act theory, a widely used approach to the philosophy of language. Philosophers of language are interested in many of the same types of problems as confront lawyers. Despite their varying points of departure, the two disciplines have reached surprisingly similar conclusions.

This Comment makes two mam points. The first is that offer and acceptance are not matters of expression or manifestation of intent. Rather, they are acts that commit the speaker to a particular course of conduct. The second major point is that although the intent of the speaker does not create the obhigation, it is nonetheless necessary that the act be accompanied by a certain state of mind. Loosely stated, the speaker must intend to create in the hearer the perception that in saying the words, the speaker is committing himself to a particular proposal.

The first Part of this Comment will review the general nature of the problem of offer and acceptance. Part II sets out the basic franiework of speech act theory. All utterances have a particular force. Some, for exaniple, assert that a particular state of affairs is true. Offer and acceptance belong to a class of speech acts that have the force of committing 
the speaker to a particular proposal. The speech act of offering must adhere to certain rules. Certain of these rules regulate the process of offering. An example of this is that an offer must be made in good faith. Other rules determine what constitutes a speech act. An example of this category in the case of an offer is the essential rule, which mandates that there be an utterance or act which "counts" as placing the actor under an obligation to carry out a proposal. Unless the essential rule has been satisfied, there has been no offer.

Part III considers what "counts" as the making of a commitment to perform a proposal. The most unambiguous way to indicate the force of an utterance is by means of a formula which is in the first person, present tense, and contams the word hereby. The force of an offer, for example, is rendered most explicit in the formula "I hereby offer you that $p$," where $p$ represents the terins of the offer. Although many words, phrases, and acts may constitute offers, this Comment will argue that an utterance or act can commit the speaker only if it is the equivalent of, or expressible as, "I hereby offer you that $p$." Although the law need not (and should not) require formulas, the legal effect of an offer or acceptance depends on whether it can potentially be expressed by means of such formulas.

Part IV deals with principles of interpretation, applying the analysis to ambiguity and its possible resolution. Part $\mathrm{V}$ addresses the interpretation of speech acts commumicated by action and inaction rather than by words. Even action and inaction can commit the speaker to the terms of a specific proposal only if they are expressible as exphicit offers or acceptances.

Finally, Part VI concentrates on the nature of intent as it relates to the law of offer and acceptance. Although the controversy is traditionally framed in terms of whether assent must be subjective or objective, this dichotomy obscures an important point. Speech act theory makes it clear that verbal acts, such as offer and acceptance, are acts much like any other. Legal responsibility attaches to an act done with a particular type of accompanying mental state. What is relevant in offer and acceptance is not whether assent is subjective or objective, but rather the nature of the acts that constitute an offer or acceptance and the mental state that must accompany such acts. A successfully uttered offer or acceptance commits the speaker to carrying out the terns of the promised act, whether or not she subjectively intended to do so at the time of the utterance.

The Nature of the Problem

The difficulty pervading the concepts of offer and acceptance is that 
there is no simple relationship between the use of the words "offer" or "accept" and legal obhgation. This is not necessarily so in all areas of legal commitinent. In soine situations a speaker inay be legally bound only if he utters a predetermined formula. During the wedding cereinony, for example, the bride and grooin can commit theinselves to one another by saying "I do," "with this rimg I thee wed," or perhaps, inerely "yes."

A famous Shia Muslim ritual allows a inan to divorce his wife by repeating, generally three times, a traditional formula called talaq. The husband may say "Thou art repudiated," "This person is repudiated," or "Such person is repudiated," but in any event inust use the Arabic word for "repudiated." Several other sects apparently have inoved away froin this strict approach and do not require specific words as long as the meaning is clear. ${ }^{2}$ A general trend away from requiring specific formulas may be seen in our own culture as well; in recent years some couples writing their own vows have eliminated the words "I do" from the wedding ceremony. ${ }^{3}$

While at one time the common law deinanded specific formulas to achieve particular legal effects, ${ }^{4}$ today an offer does not require any particular imcantation. In fact, there are cases in which use of the word "offer" does not result im a legally binding offer. For example, in Moulton v. Kershaw" the seller wrote: "We are authorized to offer Michigan fine salt, in full car-load lots of eighty to ninety-five [barrels], dehivered at your city, at 85 [cents] per [barrel]. . . Shall be pleased to

1. B. Verma, Muslim Marriage AND Dissolution 159-61 (1971); see also K. HodxInSON, MUSLIM FAMILY LAw 220 (1984). Shia law further allows a formula in question format: the husband inust answer "yes" to a ritualistic question regarding whether he has divorced his wife. B. VERMA, supra at 161.

2. B. VERMA, supra note 1 , at 159,161 . The same generally holds for marriage, which, to be effective, requires only a declaration and an acceptance. Shia law again prescribes formulas. Most other sects allow greater latitude in choice of words. Id. at 20-23.

3. This movement away from formulas can also be seen in the evolution of Roman law. Originally, legal acts had to be accomplished by prescribed verbal formulas, soinetimes accompanied by ritual actions. In the post-Classical period, however, informal legal acts became much more coinmon. M. Kaser, Römisches Privatrecht 33-36 (12th ed. 1981). An example of this progression is the stipulatio, an oral declaration of debt. The creditor asked the debtor a question which had to end with spondesne ("do you promise"), and the debtor had to answer with spondeo ("I promise"; Classical Latin had no word for "yes"). Thus the creditor might say sestertium decem milia mihi dari spondesne? ("Do you promise that you will give me 10,000 sesterces?"). The debtorto-be would then respond: spondeo. Later, other words with the same meaning were allowed, such as promittere ("promise"). By the post-Classical period, mcaning had largely triumphed over form. Id. at $40-46$.

4. See infra text accompanying notes 75-77; see also Oldfield v. Stoeco Homes, Inc., 26 N.J. 246, 139 A.2d 291 (1958) ("In the year 1564 it was not the intention of the parties that counted in the making of a contract, lease or deed. It was the words used.").

5. 59 Wis. 316,18 N.W. 172 (1884). 
receive your order." Despite the presence of the word "offer," the Supreme Court of Wisconsin held that this letter was not a legally bindimg commitment, in large part because the seller had not indicated how much salt was available. Similarly, the use of the word "offer" in "We offer the lowest prices on stereo equipment in town" would probably not bind the advertiser to sell at a specific price.

On the other hand, there are numerous cases in which the word "offer" was not used, but courts nonetheless found a binding coinmitment. Embry v. Hargadine, McKittrick Dry Goods Co. ${ }^{7}$ involved a worker whose employment contract expired at the end of the year. On December 23, he went to his boss to ask for a renewal of the contract. His employer rephed, "Go ahead, you're all right; get your inen out and don't let that worry you."8 The court held that the employer had assented to the terms of a bargain.

The crucial element is not simply the words used, but the context or circumstances in which the utterance is made. For exainple, a proposal or a price quotation does not usually constitute a legally binding offer. ${ }^{9}$ Nonetheless, some courts have found that words such as "proposal" or "quotation" are not dispositive. In Parker v. Meneley, 10 the court found that a form contract constituted an offer notwithstanding its use of the words "estimate" and "we propose."11 Similarly, the words "We quote you Mason fruit jars . . . Pints $\$ 4.50$, quarts $\$ 5.00$. . for inmediate acceptance," made in response to an inquiry, were deemed an offer despite the use of the word "quote." 12

The relationship between the word "accept" and the legal concept of acceptance is perhaps even more tenuous. The inost unequivocal acceptance occurs when the offeree states "I hereby accept your offer." Yet once again, no single formula is necessary to effectuate acceptance. For instance, the words "will exercise our option to buy ... Mail deed with draft" have been held to constitute acceptance. ${ }^{13}$ When a definite offer has been made, responses such as "it's a deal" or "you're on" generally will suffice. ${ }^{14}$

Moreover, it is now well established that the conduct of an offeree

6. Id. at 317,18 N.W. at 172 .

7. 127 Mo. App. 383, 105 S.W. 777 (1907).

8. Id. at 385,105 S.W. at 777 .

9. See, e.g., RESTATEMENT (SECOND) OF CONTRACTS $\$ 26$ (1979).

10. 106 Cal. App. 2d 391, 235 P.2d 101 (1951).

11. Id. at 395,235 P. $2 \mathrm{~d}$ at 103.

12. Fairmount Glass Works v. Crunden-Martin Wooden Ware Co., 106 Ky. 659, 51 S.W. 196 (1899).

13. Grey v. Nickey Bros., 271 F. 249 (5th Cir. 1921).

14. See Jolley Elevator Co. v. Schwegmann Bros. Giant Supermarkets, 230 So. 2d 640 (La. App. 1970) (contract formed when parties shook hauds after agreeing on price, saying that it was a deal). But at least one court has found no contract under such circumstances. See Ryan v. Schott, 
Inay constitute acceptance. ${ }^{15}$ For example, in Gomez v. Federal Stevedoring $\mathrm{Co}^{16}$ a hatch boss told several inen, including plamtiff Goinez, that they had a job in Brooklyn and that they should ineet him there at a specific time and place. The court held that by appearing at the appointed time, Gomez had accepted the offer. ${ }^{17}$ The court emphasized that both words and conduct must be given the meaning that a reasonable person would attribute to thein under the circumstances. ${ }^{18}$

An offer may further be accepted by "silence." Since conduct is often silent as well, it is better to speak of this as acceptance by inaction. A well-known case illustrating this principle is Hobbs v. Massasoit Whip Co. ${ }^{19}$ The plaintiff at times shipped eel skins to the defendant, who regularly paid for them. After the defendant had kept one particular shipment for a while, its warehouse burned and the skins were destroyed. The defendant claimed that it had never accepted the skins. Since the parties' previous conduct indicated that the defendant should have responded immediately if it had wished to reject the shipment, the court interpreted the defendant's inaction as acceptance. ${ }^{20}$

The relationship between a legally bimding offer or acceptance and the words or deeds used to express such offer or acceptance inay be indirect at best. The ambiguity inherent in words and deeds has in some cases led to the notion that when such "manifestations of assent" are unclear, the intent of the party becomes relevant. ${ }^{21}$ This relationship between what a speaker intends to communicate and the maimer in which that intention is expressed has been investigated in some detail by philosophers of language. The following Sections will discuss speech act theory and consider its relevance to offer and acceptance.

\section{II}

\section{SPEECH ACT THEORY}

Speech act theory is a philosophical approach to language, based in large part on the work of J.L. Austin and John Searle.22 The theory atteinpts to explaim how the utterances of a speaker are related to the surrounding world. Suppose that one person says "hello" to another. A

109 Ohio App. 317, 159 N.E.2d 907 (1959) (holding that parties intended to be bound only by a written agreement).

15. See, e.g., REstatement (SECOND) OF CONTRACTS § 19(1).

16. 5 N.J. Super. 100,68 A.2d 482 (1949).

17. Id. at $102-03,68 \mathrm{~A} .2 \mathrm{~d}$ at 483 .

18. Id.

19. 158 Mass. 194, 33 N.E. 495 (1893).

20. Id. at 197,33 N.E. at 495 .

21. 1 S. WILlistoN, WILlisTON ON CONTRACTS $\S \S 66,67$ (3d ed. 1957).

22. See generally J.L. AusTIN, How To Do THINGS WITH WORDS (2d ed. 1962); J. SEARLE, Speech ActS: AN EsSay in the Philosophy of Language (1969). 
linguist might be concerned with how the sounds of "hello" are produced and perceived, and might find that the greeting is unusual syntactically because it does not require a subject and verb. The philosopher of language, on the other hand, is more interested in "hello" as an expression of the speaker's intent to greet another, and in how the hearer will imterpret the utterance within the context of the conversation.

The true meaning of an utterance can differ drastically from its literal, word-for-word interpretation. If $A$ says to $B$, "Would you like to go to the movies?" $B$ will generally interpret this as a question. But now imagine that $B$ is $A$ 's seven-year-old son and that the question is "Would you like to wash the dishes?" Though still phrased as a question, the utterance is in reality a command. In the former usage this utterance has the "force" of a question, while in the latter it has the "force" of a command.

Similarly, what is syntactically an imperative need not always liave the force of a true command. A drill sergeant's "Follow me" is intended and will be understood as a command. The penalty for mistaking its force may be severe. But the same words spoken by a tour guide are best interpreted as a request or suggestion.

These examples illustrate the maxim of the philosopler Frege: only in the context of a sentence do words mean something. ${ }^{23}$ One might state this maxim even more broadly: only in context do words have meaning. Factors such as the relationslip between the speakers, as well as the subject of the discourse, are crucial to understanding. Moreover, every language has certain conventions regarding low a meaning should be conveyed. It is a convention of Enghish that certam questions regardmg the liealth of anotler person ("How's it going?" or "How are you?") usually serve as greetings rather than requests for information. Another familiar convention allows one to make a command more polite by superficially offering a clioice, as in "How would you like to do me a favor and open the door?"

\section{A. Speech Acts}

In John Searle's philosopliy of language, each attempt to coinmunicate is some type of speech act. Speecli acts consist, inter ahia, of two other types of acts: propositional acts and illocutionary acts. ${ }^{24}$ Propositional acts refer and predicate. A proposition sucl as "Sam smokes habitually" refers to Sam, and it predicates that he smokes habitually. The proposition "Donna smokes habitually" has the saine predicate but a different reference: Donna.

23. G. Frege, Die GrundLAGEN DER ARITHMETIK 73 (1884).

24. See J. SEARLE, supra note 22 , at 22-24. Searle also includes "utterance acts" and "perlocutionary acts" in his typology. 
Notice that the same proposition may occur in utterances of different types:

1. Sam smokes habitually.

2. Does Sam smoke habitually?

3. Sam, smoke habitually!

4. Would that Sam smoked habitually. ${ }^{25}$

Because the proposition in these sentences is the same, each sentence performs the same propositional act. Nonetheless, the speaker's intent with respect to the proposition is quite different. In Searle's terminology, each has a different "force." The first sentence asserts the proposition, the second asks a question, the third makes a command, and the fourth expresses a desire. ${ }^{26}$ Searle calls these acts-asserting, asking, etc.illocutionary acts, which account for the illocutionary force of utterances.

Often a specific verb expresses the illocutionary force of an utterance. In the examples above, adding such a verb makes the illocutionary force explicit, as in "I assert that Sam sinokes habitually" or "I ask you whether Sam smokes habitually" or "I command Sam to smoke habitually." Other illocutionary verbs include greet, state, describe, warn, cominand, promise, object, demand, and argue. ${ }^{27}$

More often than not, the illocutionary force of an utterance is not made exphicit by one of these verbs. If someone tells her neighbor, "I'll fix your fence tomorrow," there is no expressed illocutionary verb to indicate whether this is a mere statement of intent or an actual promise with solne moral commitment. This ambiguity is evident in that the neighbor can respond, "Is that a promise?" If the illocutionary force were inade more explicit, as in "I promise to fix your fence tomorrow," it would no longer be appropriate to ask the speaker if she had indeed promised to do so. An illocutionary verb can almost always be added to an otherwise vague or ambiguous utterance, thereby rendering explicit the illocutionary force. ${ }^{28}$

\section{B. Offer and Acceptance as Acts of Commitment}

Searle divides illocutionary acts into different classes, including representatives, directives, commissives, expressives, and declarations. ${ }^{29}$

25. Id.

26. Id.

27. Id. at 23.

28. Unfortunately, the mere use of the word "promise" in colloguial language does not guarantee that the utterance will have the illocutionary force of a promise. Suppose little Johnny has seen the neighborhood bully break a window. Not wishing to be discovered, the bully tells Johnny, "I promise to beat the tar out of you if you tell anyone." This is a threat, not a promise. A threat is a commitment to do something to someone, while a promise commits the speaker to doing something for someone. Id. at 58.

29. See Searle, A Classification of Illocutionary Acts, 5 LANGUAGE Soc. 1, 10-15 (1976). For a 
Important for present purposes is that assertions and statements are both representatives - they represent that something is true. Talking about offering and stating the price of an item are both representatives. They reflect reality or the state of mind of the speaker instead of ordering relations between speaker and hearer.

In contrast, commissives such as "offer," "accept," and "promise" commit the speaker to a proposed future course of action. These illocutionary acts differ radically from assertions of a particular intent. Any statement or expression of imtent is valid only to the extent that it reflects the actual, subjective intent of the speaker. With a commissive, the speaker commits himself to carrying out the proposed act, whatever his actual intent and even if he later changes his mind. As Austin pointed out, "when I say 'I promise', a new plunge is taken: I have not inerely announced my intention, but, by using this formula (performing this ritual), I have bound myself to others, and staked my reputation, in a new way." 30

The important distinction between representatives (such as assertions) and commissives (such as offers and acceptances) is that the former represent the proposition to be true while the latter commit the speaker to having a particular intent. ${ }^{31}$ The utterance "I hereby offer you my car for $\$ 500 "$ may be insincere, but it is not true or false in the normal sense of those words. On the other hand, "We offer the best deal in town" is a verifiable statement about reahty, seinantically analyzable as "We assert that we offer the best deal in town." Its truth depends on whether there is in fact a better deal within the city limits. Thus in the second sentence, "offer" does not imdicate the force of the utterance. The sentence is, rather, an assertion about offering that does not commit the speaker to a proposal.

\section{Elements of the Speech Act of Offering}

There are two fundamentally different types of rules that relate to illocutionary acts such as offering. One of these types, called constitutive rules, defines what constitutes a particular act. The other type, regulative rules, refers to how the act ought to be carried out. ${ }^{32}$ When a regulative rule has been broken, something is wrong with the offer or acceptance, but it is still a valid speech act. In contrast, where the constitutive rules have not been met, there has been no offer.

discussion of other classifications and proposed refinements to Searle's model, see Hancher, The Classification of Cooperative Illocutionary Acts, 8 LANGUAGE SOC. 1 (1979). Hancher briefly discusses contracts in his article. Id. at 7-8.

30. J.L. Austin, Other Minds, in Philosophical Papers 76, 99 (3d ed. 1979).

31. J.L. AustiN, supra note 22, at 47. This is similar to Austin's original notion that performatives did not have truth value.

32. J. SEARLE, supra note 22, at $33-42,63$. 
Among the regulative rules of offering are certain preparatory rules. ${ }^{33}$ Two examples of preparatory rules are that the speaker must be willing to accept the hearer's promise or act in exchange for the speaker's promise, and that the speaker inust beheve that the hearer is willing to accept the speaker's promise in exchange for the hearer's promise or act. Although this analysis is meant to reflect linguistic or social notions of offer and acceptance, the law seems to have recognized these rules, at least in part, by its requirement of good faith dealing. Another preparatory rule is that it cannot be obvious that either of the parties would do the promised act anyway in the nornal course of events. Finally, it is probably also a precondition that the speaker beheve that he can carry out the promised act and that he beheve that the hearer can perform his part of the bargain.

The sincerity rule requires that the speaker intend to perform the promised act and to accept the hearer's act in exchange. The person who inakes an offer (or a promise) ought to intend to carry out the predicated act. This is the meaning of sincerity in this context. Only because sincerity is expected is it possible to state-as most people would-that an insincere offer or promise is objectionable. At the same time, an insincere offer is an offer nonetheless. In fact, insincerity cannot exist until there is an act of commitinent. The reason that insincerity (at least when not obvious) does not invahidate the speech act is that the sincerity rule is a regulative rule of offering. One ought to be sincere when offering, but sincerity is not one of the elements that constitute offering or accepting. ${ }^{34}$

Another of the conditions on offering is expressed in the propositional content rule. The propositional content (proposed bargain) must specify a promise of the speaker in exchange for a promise or a future act of the hearer. An offer is more than a promise that is conditional on a promise by the other party. A promise conditioned on another person's also making some promise commits the speaker only to his own promise, which goes into effect when the other person makes his proinise. In contrast, an offer commits the speaker not only to his own promise, but also to accepting a specific promise or act in exchange. This rule is obviously related to the legal requirement of mutuality.

The essential rule states that the speaker must utter language that "counts as" a commitment to carrying out the terms of the bargam. ${ }^{35}$ This requirement, of course, is conditional on acceptance by the offeree.

33. These and the following rules are based on Searle's analysis of promise, modified to apply to offer and acceptance. See J. SEARLE, supra note 22, at 54-71.

34. For a discussion of the sincerity rule and its relationship to the state of mind that must accompany the illocutionary act, see Part VI.

35. The terminology "counts as" is taken from J. SEARLE, supra note 22, at 63 . The phrasing is rather awkward, but to speak of an "utterance that commits the speaker" must be avoided as conclusory. 
Unlike the other rules, the essential rule must be met for there to be an offer, simce it defines what constitutes an offer or acceptance. In addition, language that counts as an act of commitment creates a presumption that the act has been carried out in accordance with the regulative rules. Unless there is evidence to the contrary, the fulfillment of the essential rule imples that the other (regulative) rules have been satisfied.

The essential condition for an offer is generally the same as that for acceptance. Both require language that counts as putting the speaker under a commitment to carry out the terms of the bargam. In contrast, the essential condition for a statement or assertion, categories that include talking about offermg and preliminary negotiations, is that the utterance or act count as representing an actual state of affairs. Someone who states that she imtends to sell her automobile for two thousand dollars is representimg this as her actual state of mind, but she does not commit herself to it.

In addition to an utterance or act which counts as placing the speaker under a commitment to perform the bargam, it is also essential that the speech act be accompamed by a particular intent; this will be analyzed later. ${ }^{36}$ The next Parts explore the way in which certain utterances, acts, and maction can fulfill the definition of an offer or acceptance. In other words, they will discuss what "counts" as a cominitment to perform the terms of an agreement, and how this can be determined.

\section{III \\ The Equivalence Test}

The essential element of an offer or acceptance is that there be an utterance or other communication that counts as placing the speaker under an obhigation to perform the terms of the proposed bargain. ${ }^{37} \mathrm{~A}$ crucial question, therefore, is what sort of language can perform this function. It has been seen that the word "offer" is neither necessary nor sufficient to create commitment. On the other hand, there is no doubt that "offer" can at times imdicate the illocutionary force of offering. The following sections explore the nature of words that are conventionally taken as committing the speaker to a bargain.

\section{A. Performative Verbs}

One of the original insights of the philosopher Austin was his characterization of certain verbs as performatives. Verbs of this type do not just describe an action or state of affairs, but in fact perform an act or

36. See infra Part VI.

37. See supra text accompanying note 35 . 
bring about a state of affairs. ${ }^{38}$ In a marriage ceremony, the words "I do" bring about the state of matrimony. Similarly, the words "I promise" commit the speaker to doing a particular act in the future. It is not, it should be stressed, the intent to promise that commits the speaker, but rather the uttering of the words themselves. ${ }^{39}$

The words "offer" and "accept" nay be used as performatives, where the speaking of the words ipso facto constitutes the act of commitment. But aside from constituting an act of commitment, the words "offer" and "accept" inay simply describe the acts of offerimg and accepting. When "offer" describes the making of a commitment (instead of actually creating a commitment), it is usually part of a representative speech act. For example, in "We offered him our house for $\$ 100,000$," the verb "offer" describes an act of commitment in the past. The sentence performs the act of asserting, as is made explicit by the paraphrase "I assert that we offered him our house for $\$ 100,000$."

When the word "offer" is used as a performative, it clearly indicates the force of the utterance. ${ }^{40}$ In other words, the performative use of "offer" (or "accept") unambiguously "counts" as committing the speaker to performing the proposed bargam. For this reason, it is worth examining the notion of performative verbs more closely.

Austin pointed out that a perforinative verb must be in the first per-

38. See generally J.L. AustiN, supra note 22, at 1-11.

39. Since performative verbs (especially in Austin's original sense) change reality instead of simply discussing it, they often carry legal consequences. A person who says or writes "I hereby bequeath" has not only stated what she intends to have happen after her death, but also has, under the proper circumstances, created a legal obligation. The statement "I guarantee this loan" may also create an obligation, just as "I offer," "I promise," or "I accept" can.

The rules of evidence support the notion that performative verbs are deeds as well as words. As a general principle, hearsay evidence is inadmissible. See, e.g., MCCORMICK ON EVIDENCE $\S \S 244-$ 253, at 724-58 (E. Cleary 3d ed. 1984). Yet when a witness reports that soineone used a performative verb, the testimony is allowed into evidence because it is a report not simply of words, but of a deed. Id. $\S 249$, at 732-33.

Evidence of intent-at least, of subjective intent or state of mind-is not admissible under this exception to the hearsay rule. McCormICK, supra, § 249 at 732, n.2. This supports the idea that speech acts are distinct from statements of intent. For comments by a linguist on the hearsay rule, see Hancher, Speech Acts and the Law, in LANGUAGE USE AND THE USES OF LANGUAGE 245, 249 52 (R. Shuy \& A. Shnukal eds. 1980).

That offer and acceptance are acts instead of simply statements of intent is suggested in the work of Ferson, who speaks of "juristic acts" which change the actors' legal relations. Ferson, The Formation of Simple Contracts, 9 CORNELl L.Q. 402, 405 (1924). But the basic notion was in fact recoguized much before either Ferson or Austin. The seventeenth-century scholar Lessius wrote, "Ratio est quia promissio et donatio sunt signa quaedam practica, efficientia idipsum quod significant ... qui enim dicit, Promitto tibi, Do tibi, non solum significat internam cogitationem ... sed etiam ipsum actum donationis \& promissionis." L. Lessius, DE IUSTITIA ET IURE 219 (1628) (lib. 2, cap. 18, dub. 5) ("The reason is that promise and gift are practical sigus effecting that which they siguify ... whoever says, I promise or I give, siguifies not only an interual thought, but also the act itself of giving and promise").

40. This has also been pointed out by Samek, Performative Utterances and the Concept of Contract, 43 Australasian J. Phil. 196, 200-02 (1965). 
son, present tense. ${ }^{41}$ "I offer" is usually a performative, as is the plural "we offer." On the other hand, "she offers" or "you offer" is not normally a performative, but serves only to describe offering. The use of anything but the first person is generally a sign that the verb is not functioning as a performative. The same holds true when the verb is not in the present tense. The phrases "I offered" or "we will accept," though in the first person, are nonperformative uses of the words "offer" and "accept." Since the use of a performative constitutes the doing of the act itself, only the present tense is appropriate.

The above criteria alone will not isolate performative from nonperformative uses of "offer." Austin suggests another useful test: only a performative phrase can contain the word "hereby."42 "Hereby" is never required in a performative construction, but every performative sentence allows its imsertion. Note the appropriateness of this word in performative utterances such as "I hereby gnarantee" or "I hereby proclaim" or "I hereby appoimt." Contrast this to sentences where "hereby" calmot be inserted: "I hereby promised you to help inow the lawn" or "I hereby might accept your offer." This test can identify a first-person, present-tense occurrence of "offer" that is nonetheless a description or an assertion. An example is "We offer the best deal in town." Despite the person and tense of the verb, the sentence fails the "hereby" test. "We hereby offer the best deal in town" is not grammatical, unless perhaps the speaker is simultaneously making a specific proposal. But in a general claim, unattached to a particular bargain, the insertion of "hereby" is inappropriate.

These considerations suggest that the prototypical way to cominit oneself to a proposed bargain is by uttering the formula "I hereby offer you that $p$," where $p$ indicates the proposition. This formula inakes explicit the performative function of "offer"; uttering the formula unambignously counts as an act of commitment. Beyond this, a legal offer must obligate the speaker to an exchange of promises. This factor could be made explicit by mcluding the proposition in the formula, perhaps as "I hereby offer you that (I promise to do $A$ and you promise to do $B$ )." The proposition goes into effect once the offeree says, "I hereby accept your offer."

Uses of "offer" that camiot be cast into this formula nornally

41. J.L. AUSTIN, supra note 22, at 57.

42. Id. at 57-58.

43. Of course, a promise can also be exchanged for an act, in which case the formula would be something like "I hereby offer you that (I will promise to do $A$ if you will do $B$ )." Here the promise to do $A$ is conditional, since it hinges on the doing of $B$. It does not create an obligation to do $B$, however. With a bilateral agreement, the promises are not conditional and are therefore conjoined by "and." There, it is the entire exchange of promises that is conditional on acceptance by the offeree. For further comments on the content of the proposal, see supra text following note 34 . 
involve illocutionary acts of stating or asserting. It is generally safe to assume that phrases such as "we may offer," "we intend to offer," "we will offer," and "we offered" have the illocutionary force of an assertion or statement. Such utterances are semantically equivalent to "We assert that we intend to offer," in which "offer" is part of the proposition rather than an imdication of the illocutionary force. ${ }^{44}$

But although the formula can make explicit the force of an offer, the vast majority of offers and acceptances in all likelihood do not use a performative phrase of this kind. Indeed, many binding commitments to a proposal do not use the words "offer" or "accept" at all. Rather, the formula is the prototype for language that counts as committing the speaker to a proposed bargain. Any utterance, action, or failure to act that purports to perform the act of offering or accepting must be the equivalent of, or expressible as, these formulas for offer and acceptance.

\section{B. Applying the Equivalence Test}

The essential rule requires that a valid offer contain language that counts as putting the speaker under an obligation to carry out a proposed bargain. The rule is most exphicitly satisfied by the performative expression "I hereby offer you that $p$. ." Because they so decisively commit the speaker, formulas were long favored by the law. Of course, there are many other ways to make offers, as long as the language is equivalent to the formula. Put slightly differently, any valid offer must be expressible as "I hereby offer you that $p$," just as an acceptance must be expressible as "I hereby accept your offer." The following Section will discuss this equivalence test more fully.

\section{1. "I"}

An offer is legally bimding only if the offeror commits herself to per-

44. Although an auxiliary verb may establish a presumption that "offer" does not indicate the illocutionary act of offering, sometimes a true offer is made despite language qualifying the word "offer." In King v. Seaboard Air Line Ry., 140 N.C. 423, 53 S.E. 237 (1906), the defendant sent a telegram to the plaintiff with the words "can offer you extra force at $\$ 65$ per month." The court held that this was an offer, despite the presence of "can." One commentator has disagreed, arguing that "can offer" should not have been accorded the force of a legally binding offer. Note, ContractsDistinction Between Offer and Preliminary Negotiation, 29 N.C.L. REV. 47, 48-49 (1950).

This Comment, however, presents an unrealistic view of speech conventions, interpreting the language too literally for the circumstances. Auxiliary verbs such as "can" and "will" are frequently utilized to add emphasis, rather than to express possibility or futurity. For example, "I can promise you that we'll find the man who killed your husband" would normally be interpreted as a genuine, perhaps emphatic, promise instead of a statement that it is possible for such a promise to be made. Similarly, "I'll tell yon one thing ...," is an emphatic telling, not a statement of what will happen in the future. On the other hand, "would," "might," "may," and "could" do not have such conventional usages and are thus strong evidence that the verb that follows is part of a statement of ability or probability. Cf. Gordon \& Lakoff, Conversational Postulates, in SyNTax \& Semantics 3: SPEECH ACTS 102-03 (P. Cole \& J. Morgan eds. 1977). 
forming her part of the bargam or to ensuring that someone else carries out the bargam for her. ${ }^{45}$ The "I" in the forinula "I hereby offer you that $p$ " mdicates that this is an integral part of a legally cognizable offer or acceptance. A speech act is legally binding ouly if it is expressible as an utterance which has as its subject (more accurately, its logical agent ${ }^{46}$ ) a first person pronoun. ${ }^{47}$

In some sentences, the "I" or "we" is not exphicitly stated, but it is nonetheless obvious that the speaker is the person committing herself. For instance, "your offer is accepted by us" is a valid acceptance. This sentence may be seen as syntactically derived from, and expressible as, "we (hereby) accept your offer." 48

While a logical agent is explicitly expressed in many sentences, it is sometimes omitted altogether, as in the passive sentence "Your offer is accepted" or "Passengers are warned to duck their lieads before oncoming tunnels." The latter expression is ambiguous; if a "hereby" can be inserted before "warned," the sentence perforins the act of warning. Otherwise, the sentence simply reports that passengers are routinely warned before approaching turmels. Only in the first sense is the utterance expressible as "We liereby warn passengers to duck their heads before oncommg tunnels." With the second meaning, the sentence might be equivalent to "We assert that soineone warns passengers to duck their heads before oncoming tuimels." The crncial point is that in the latter sentence the unstated agent could be any person, while im the foriner the unstated agent must be the speaker.

Contracts are often written in the third person, as in "The party of the first part promises to pay to the party of the second part one thousand dollars." Many letters containing job offers employ similar conventions: "Jones and Jones is pleased to offer you a one year renewable contract at $\$ 20,000$ per year." In each case, it is evident that the parties are committing themselves; the sentences could be rephrased as forinulas containing "I" or "we."49

45. S. WILliston, supra note $21, \S 1 \mathrm{~A}$.

46. "Agent" is used here in a linguistic sense. The logical agent is the "doer," and hence the subject in an active sentence such as "I ate the fisl.." In the corresponding passive sentence, the logical agent is the object of the preposition "by": "the fish was eaten by me." Even though the surface subject in the latter sentence is the fish, "I" or "me" remains the logical agent.

47. J.L. AustiN, supra note 22, at 61-62. Austin suggests that the question is whether a less explicit utterance is reducible to an explicit performative. This is the essential thrust of the equivalence test.

48. Noam Chomsky's early theory of transformational grammar maintained that passive sentences are derived from the same deep structure as active sentences. See N. CHOMSKY, SYNTACTIC STRUCTURES $42-43$ (1957).

49. Austin suggests that when there is no reference in an utterance to the person who is performing the speech act (the "I"), that person refers to limself by being the one who speaks. In written utterances, the function of associating a speech act with its origin may be accomplished by signing the document. J.L. AustiN, supra note 22, at 60-61. 
A more interesting variation occurs where the offer is made through an intermediary. For example, John wishes to sell his bicycle to Bill, but knows he will not see Bill for soine time. He therefore asks Susan to offer the bicycle to Bill for $\$ 50$. Susan meets Bill and says to him, "John offers you his bicycle for $\$ 50$." This is a valid offer, although Susan's utterance does not seem to be expressible as "I hereby offer you $p$. " But since Susan is merely a legal agent, she functions as a conduit from John to Bill, taking the place of John in the conversation. From that poimt of view, the offer $i s$ the equivalent of "I hereby offer you my bicycle for \$50." Language judgments confirm this function of agency. It is nonsense to say "John Doe hereby offers you one acre of land for $\$ 3000$ " unless the hearer has reason to know that the speaker is acting for Doe. Thus this superficial exception to the requirement that "offer" have a first-person subject actually confirms the rule.

\section{2. "Hereby"}

The use of "hereby" in legal language has been criticized as an anachronism kept alive by a stuffy profession. Mellinkoff condemned it as "a great favorite" of lawyers. ${ }^{\text {so }}$ But while it is relatively easy to dispense witl "whereby" or "hereunder," the use of "hereby" has long persisted.

There is a straightforward reason for this persistence. A speech act is not merely a communication of the speaker's intent to offer or promise; it is the act of offering or promising itself. Although not grammatically required, the presence of "hereby" in the formulas " $I$ hereby offer you that $p$ " and "I hereby accept your offer" indicates that by this very utterance the speaker is performing the act in question.

Intent to offer or accept cannot and should not, without more, bind the speaker. One caimot say, for example, "I hereby intend to carry out my part of the bargain," since intending is not an illocutionary act. Rather, it is the offer or acceptance itself that binds the speaker. The speech acts of offer and acceptance, as indicated by the word "hereby," constitute assent to the terms of a bargain; they do not simply manifest assent.

\section{3. "Offer"}

An offer either must use the verb "offer" im a performative sense or must be expressible as such. However, not all performative uses of

50. D. Mellinkoff, The Language of the Law 313-14 (1963). In more "primitive" societies some ritualistic acts or signs perform the function of signaling (like "hereby") that the speaker or actor is engaging in a legally binding act. In early English law, putting agreements under seal made them binding. If the seal was destroyed-even if by accident-the obligation dissolved. $\mathrm{S}$. WILLISTON, supra note $21, \S 205$, at 765-66. 
"offer" constitute legally cognizable offers. In the sentence "I offer to take out the trash tonight," the nieaning of "offer" might be paraphrased as "nrake a proposal." Another example where "offer" is used in a performative sense, without legal consequences, is the sentence "I offer you my services." In this context, "offer" is roughly equivalent to "Inake available" or "present." This use of "offer" is very nearly a legal one; both in the above sentence and in "I hereby offer you my horse for $\$ 500$," the speaker presents or inakes available a proposal to the hearer.

The word "offer" in all these examples has the nueaning of presenting or proposing a promise. When no other verb is explicitly stated, speakers assume the verb "to give" in the senuantic structure of these sentences. Thus, "I offer you nry services" is semantically equivalent to "I propose that I promise to give you my services." Similarly, "I offer to take out the trash" is semantically equivalent to "I propose that I pronIise to take out the trash."

"Offer" is used in a legal sense only when the other required eleinents-especially the propositional content rule-are fulfilled. ${ }^{51}$ If in place of "I offer you my services" the offeror had said "I offer you niy services for five dollars an hour," an enforceable offer might have been inade, since upon acceptance promises have been exchanged. By way of contrast, "I offer to take out the trash" is not a legal offer because there is no mutual exchange of proniises.

\section{4. "You"}

An offer must express commitnient to a specific person. Not everyone who hears the offer has the right to accept it. The presence of the "you" in the formula "I hereby offer you that $p$ " is crucial to determining that the offer is benig nrade in a legal sense. The absence of "you" nray have been significant in Moulton $v$. Kershaw, ${ }^{52}$ in which the offeror sent a telegram stating, "we are authorized to offer Michigan fine salt . . . at 85 [cents] per [barrel]."53 The lack of a "you" suggests that this communication is a statement regarding price rather than a performative. Had a "you" been present, it would have suggested that the seller was conimitting himself to the potential buyer.

In Carlill v. Carbolic Smoke Ball Co., ${ }^{54}$ the defendants placed the following advertiseinent in the Pall Mall Gazette: "[f]100 reward will be paid by the Carbohic Snioke Ball Conipany to any person who contracts the increasing epidemic influenza, colds, or any disease caused by taking

51. See supra text accompanying notes 32-35.

52. 59 Wis. 316,18 N.W. 172 (1884).

53. Id. at $317,18 \mathrm{~N} . \mathrm{W}$. at 172 .

54. [1893] 1 Q.B. 256 (C.A. 1892). 
cold, after having used the ball three times daily for two weeks . . .."55 The court held that anyone who performed the conditions of the advertisement was an offeree and could bind the offeror by acceptance of the proposal. Applying the foregoing analysis, the relevant question is whether the plaintiff, who bought a smoke ball but nonetheless became sick, was justified in viewing herself as soineone to whoin the sinoke ball coinpany was committing itself. The court held that the offeror was committing itself to any reader who fulfilled the conditions, and that the plaintiff was indeed a "you."

Another case illustrating the importance of the "you" element is Mayor of Jersey City v. Town of Harrison. ${ }^{56}$ The town of Harrison passed a resolution to buy water from Jersey City. Before this was transmitted as an offer through official channels, Jersey City acquired a copy of the resolution and tried to bind Harrison to its terms. Certainly the Harrison resolution manifested an intent to inake an offer on specific terms. But Harrison passed the resolution for its own internal purposes. Could Jersey City interpret this as an utterance expressible as "We hereby offer you that $p$ ?"

Inherent in the "you" of the formula is that an offer is ineaningless until the speaker communicates it to the offeree or at least makes provisions to accomphish that goal. The statement "hello," which is equivalent to the explicit performative "I hereby greet you," is appropriate ouly if the speaker can in some way direct the greeting to the recipient. The speaker nnight even proclaim her message on a billboard, but it will function as a greeting ouly if the recipient is expected to see it. Therefore, the resolution in Jersey City could not be expressed by a formula which contains "you," given that the Harrison city council had not addressed the proposal to officials in Jersey City.

The requireinent that an offer or acceptance be commumicated to the other party flows naturally from formulas such as "I hereby offer you that $p$. ." Only if "you" can appropriately be inserted into the phrase can the statement have the illocutionary force of offering or accepting. Thus, the requireinent that an offeree must have notice of an offer is less an external constraint placed on the validity of contracts im the interest of justice than it is a necessary component of the speech act. ${ }^{57}$

55. Id. at 257 .

56. 72 N.J.L. 185, 62 A. 765 (1905).

57. Not all performative verbs demand a "you" as indirect object. "Bequeath" does not-the appropriate formula might be something such as "I hereby bequeath $X$ to $A$," without a "you." As a consequence, bequeathal is effective without notice to the heir. Analogously, one possible formula used for talaq in Shia Moslem divorce does not contain a "you": "this person is repudiated" or "such person is repudiated." See supra text accompanying note 1. As would be expected, it is not necessary that the words be addressed to the wife or that she even have notice. B. VERMA, supra note 1 , at 160; K. HodKINSON, supra note 1, at 220. 
It bears emphasizing that each element of the formula need not be present in a simgle utterance, as long as the missing eleinents can be inferred from context. For instance, someone might pass a sign in a window stating, "Teinporary help needed-five dollars an hour-inquire within." If she enters and says "I offer my services," she has argnably made a valid offer. Although the sign does not contain the word "you," it is evident that the offer is made to the offeree, since the speaker entered the building and addressed the person in charge of hiring.

\section{Acceptance}

Acceptance operates in much the same way as offer. Although there are diverse ways im which one can accept an offer, all acceptances must be equivalent to uttering the formula "I hereby accept your offer." A party can accept an offer by affixing a signature to the contract, by shaking hands with the other party, or by remaining silent when there is held to be a duty under the circumstances to reject an offer. But all these words and actions must have the illocutionary force of accepting. In most respects, the act of accepting greatly resembles offering-there must be language (or action) that counts as committing the speaker to the bargain. The main difference is that the offeree must accept or reject the terms as presented by the offeror.

Few real-life offers or acceptances actually are cast in the stereotyped formulas discussed above. The following sections will explore some of the ways in which lingnistic analysis aids in the determination of whether an utterance or act is expressible as "I hereby offer" or "I hereby accept." Although the utterances or acts may vary widely in outward form, the same basic elements must always be present for there to be a vahid offer or acceptance.

\section{IV}

\section{INTERPRETATION}

In normal conversation the content of an utterance, including its illocutionary force, is often expressed indirectly. The circumstances and context of the utterance assume great importance in deciphering the meaning of such speech acts. The sentence "Do you think that you could open the door?" might under some circumstances be a question equivalent to "I ask you whether you think that you are able to open the door." This would be the correct interpretation if the parties are standing before the five meter high portals of a medieval castle. On the other hand, when the speaker is returning home with large bags of groceries, the saine sentence is a request or even a coininand. The rest of this Part suggests some tecliniques which participants in the speech setting use to 
interpret an utterance in context and to determine whether it has the requisite eleinents of an offer or acceptance.

\section{A. Ambiguity and Meaning}

Often utterances seein hopelessly ambiguous. Even words which have only one dictionary meaning can develop other ineanings through inetaphorical extension. At the other extreme, a word such as "right" has a large variety of dictionary ineanings. Context will usually allow the hearer to extrapolate the intended meaning. For example, "right" is clearly a directional term in the sentence "The house is on the right."

Ambiguity results when the intended meaning does not emerge from the context. If a driver asks her passenger, "Should I turn left here?" the passenger might reply, "Right." Most meanings of "right," such as "conservative" or "privilege," are eliminated by the linguistic context. Still, two competing meanings remain: the opposite of "left" and the opposite of "wrong." Unless a difference in intonation or something in the extralinguistic circumstances indicates the intended meaning (for example, if a right turn were physically impossible), the utterance "right" is ambiguous.

A formnla such as "I hereby accept your offer" is the most exphicit way to make an offer or acceptance. It is probably inore common, however, for assent to be made indirectly, where the words do not literally indicate the force of assent. An example is an offer that states "Will you take ten dollars for that watch?" Obviously, this question creates greater possibilities for ambiguity than does the use of a formula. Nonetheless, where such indirect utterances are equivalent to exphicit performatives, the utterance will count as putting the speaker under a commitment to abide by its terms. The rest of this Section will deal with how words can indirectly commit the speaker to the terms of an agreement, and will further demonstrate how ambiguities, at timies, can be reduced or eliminated.

\section{B. Idiomatic Meaning}

A sentence such as "Can you open the door?" has at least two meanmgs. The first is a fairly literal meaning, one in which the whole of the sentence is roughly equal to the sum of its parts. In its most direct sense, "can" refers to the ability to carry out a task. Yet "can you" is often used idiomatically to give an order. This accounts for the other meaming of this sentence. A dramatic example of this use of "can" occurred when an American officer told a soldier, "Do you think you can take this

58. See M. Beardsley, Thinking Straight 153-59 (2d ed. 1956). 
Korean and shoot him?"59 There is little doubt that the officer intended to give an order; liad he said, "Do you think you can take this trash can and empty it?", the soldier could not have answered "Yes" and done nothing more witlout incurring dire consequences.

Otlier idiomatic expressions, such as "would you" and "will you," may be used to issue directions im addition to simply asking questions. ${ }^{60}$ Examples are "Will you open that door for me?" "Would you swat that fly?" or "Would you like to wash the dishes?" These and other expressions, therefore, may liave a conventional illocutionary force different from or in addition to their literal meaning.

There are a number of expressions that do not literally indicate the illocutionary force of offer but that do so idiomatically. For example, auxiliary verbs that indicate possibility or ability can occur in sentences that have the illocutionary force of an offer. "We can offer you," "We are able to offer you," or "It is possible for us to offer you" may all, in the proper circumstances, have the force of offer despite the superficial waffling.

Phrases that literally refer to a positive state of mind also may have the illocutionary force of offer. Examples are "We would like to offer you $p$ " or "We are pleased to offer you $p$." Normally it is not enough that one "would like" to offer or accept, but in ordinary language these expressions usually count as committing the speaker to an offer. The sentence "We would like to offer you a job at Simth and Smith" has the illocutionary force of an offer despite the presence of "would like." On the other hand, in the sentence "We would like to offer you a job at Smitli and Smitll, but have insufficient funds this year," the context militates against the nonliteral interpretation.

Verbs referring to authority may co-occur with the word "offer" witlout robbing the expression of the illocutionary force of offer: "We have been authorized to offer you $p$," or "We have been permitted to offer you $p . "$ This is true even thougli literally being authorized or permitted is simply a preliminary step to offering.

Finally, offers may be made witlout using the word "offer" at all. For example, sentences sucl as "Will you take five dollars for that hat?" or "Will you sell ine your bicycle for fifty dollars?" may count as committing the speaker to pay fifty dollars for the bicycle. Altliough these utterances are literally requests for information, in a bargaining context

59. United States v. Kinder, 14 C.M.R. 742 (A.F.C.M.R. 1954). "Lieutenant Schreiber did not use the words 'Kill the Korean' [but in the soldier's] opinion he had received an order to shoot the Korean." Id. at 761-62.

60. See generally Searle, Indirect Speech Acts, in SyNTAX AND Semantics 3: SPEech Acts 59 (P. Cole and J. Morgan eds. 1975); see also Fraser, Hedged Performatives, in SYNTAX AND Semantics, supra, at 187. 
they usually function as the equivalent of "I (hereby) offer that I will promise to pay you fifty dollars and you will promise to give me your bicycle."

Acceptance also can be expressed idiomatically. In response to an offer, a person could reply "You're on," "It's a deal," or "You've got yourself a bargain." If asked the question "Will you sell me your bicycle for fifty dollars?", the offeree could simply respond with "yes." The crucial issue is whether the speaker has uttered the equivalent of an exphicit performative, and so has committed herself to the terms of the bargain.

\section{Grice's Maxims of Conversation}

The use of idiomatic expressions often leads to superficial anbiguity, since the language generally will have both a hiteral (word-for-word) meaning as well as the more idiomatic meaning. The hearer must determine which of these meanings is intended. Native speakers of the language contimually make such judgments. Courts would frustrate the will of the parties if they looked only to the most hteral meaning of the words used.

Judges have become increasingly amenable to interpreting less exphicit speech acts as native speakers of the language would. In Embry v. Hargadine, McKittrick Dry Goods Co., ${ }^{1}$ an employer responded to a worker's question about renewal of his employment with the words: "Go ahead, you're all right; get your men out and don't let that worry you." "62 The words "don't let that worry you," ainong others, were found to constitute acceptance of the offer. In the terms of this analysis, they were found the equivalent of "I hereby accept your offer." Had the court rehed only on the hiteral meaning of the words, it could never have reached this conclusion. But the court recognized that "don't worry about it" or similar phraseology often is used idiomatically as a promise to remedy the source of the worry. If two people enjoy an expensive dinner and one finds himself short of cash, his diming partner may say, "Don't worry about it," thereby implying that he will pay for the meal. Notice that this implication only apphes to phrases closely resembling "Don't worry about it." "Don't be so paranoid" and "Worrying will get you nowhere" do not normally constitute a promise to pay.

A useful method for determining the meaning of these kinds of anbiguous utterances is a notion advanced by the philosopher Grice, which he calls conversational implicature. ${ }^{63}$ Conversational implicature

61. 127 Mo. App. 383, 105 S.W. 777 (1907). The case is discussed supra text accompanying notes 7-8.

62. Id. at $385,105 \mathrm{S.W}$. at 777.

63. Grice, Logic and Conversation, in SyntaX AND Semantics 3: Speech Acts 45-46 (P. Cole and J. Morgan eds. 1975). 
is based on a set of maxims that operate as rules of conversation. While the maxims may seem self-evident or even simplistic at first, they are useful botlı in eliminating unintended meanings and in inferring ineanings that are not immediately evident. In other words, tliese maxims lielp make exphcit what it means to say tliat utterances can only be understood in context or under particular circumstances.

What Grice calls tle "cooperative principle" - an overarching principle governing most conversation-is central to conversational implicature. This principle rests on the observation that participants im a conversation normally cooperate witlı one another. For exainple, a person will usually try to make eacli utterance on a particular topic relevant to the preceding utterance. This being so, parties to a conversation will interpret an utterance as being cooperative-im this case, as being relevant to what went on before.

Various maxims derive from the cooperative principle, which is divided into a number of categories. The category of quantity includes two maxims: make your contribution to a conversation as informative as necessary and, conversely, do not make your contribution more informative than is required. The category of quality also contains two maxims: a contribution should be true and the speaker should have adequate evidence for it. The category of relation contains a maxim mandating that a contribution be relevant. Finally, the category of manner includes maxims promoting brevity, clarity, and the like. ${ }^{64}$

These maxims clarify the result in Embry v. Hargadine. The primary reason tliat "Don't worry about it" can constitute acceptance of the employee's implicit offer has to do with Grice's conversational maxim of relevance. A literal interpretation of the einployer's statement would not be a relevant answer to the employee's concern. Therefore, this possible interpretation can be eliminated. All that reinains is the more idiomatic meaning of tlie phrase as a promise to dispose of the employee's concern. The employer's response was relevant only as an acceptance.

The inaxims of relevance and quantity also account for the force of many of the less direct offers discussed above. ${ }^{65}$ Consider the question, "Will you take five dollars for that bowl?" If a friend says this to a potter, after the potter has said that she hopes to sell it for six dollars, it would be relevant as a question and would be interpreted as such. But if the utterance is made by a potential customer, in response to the potter's

64. Id. Interestingly, the cooperative principle does not always seem to apply in the context of a deposition. Consider the question "Can you tell us whether your coinpany has ever discussed this matter?" Apparently, a deponent can answer "yes" to this question, even though the company has never discussed the matter. But for the context of the deposition, he would have violated the maxim of quantity, which requires that you inake your contribution as informative as is expected. In normal conversation the statement would have been a lie, or at least not the whole truth.

65. See supra text accompanying notes $60-61$. 
offer to sell it for six dollars, the utterance is most relevant not as a question, but as a counter-offer. Similarly, suppose that a job applicant receives a letter stating, "We are authorized to offer you a position." Under these circumstances, the letter im its hiteral sense communicates both too much information and too hittle-it announces the employer's authorization while failing to disclose whether an offer will be forthcoming. Only interpreting the letter as an actual offer is responsive to the applicant's implicit question as to whether he will in fact obtain an offer.

\section{Assent by Implication}

\section{Implication in General}

Grice's maxims also help interpret speech acts where the meaning is not idiomatic but must be inferred from the circumstances. In other words, the maxims also apply to utterances that imply an offer or acceptance. ${ }^{66}$ In such cases the maxims do not eliminate mappropriate meanings, as when an idiomatic meaning competes with a literal meaning, but rather give words an interpretation that they would not have otherwise. If a duke tells his servant, "There's a draft in here," there is little doubt that this is an order to close the window. The order, though not one of the conventional meanings of this utterance, is implicit in the circuinstances, especially the relationship of the duke to his servant.

A similar example is where a job applicant receives a letter thanking him for applying and telling him that the firm has completed its hiring process. The applicant can easily infer that he has been rejected. Grice's maxim of quantity, which states that one should say neither too much nor too hittle for the purposes of the conversation, provides an explanation. ${ }^{67}$ If the applicant had gotten the job, one would expect the letter to say so explicitly; otherwise the letter would not have been adequately informative for the purposes of the "conversation." Lack of an offer where one would be expected implies that no offer is forthcoming.

Much the same principle operates when a professor writes a letter of recommendation for a student. Suppose that the letter, after the customary greeting, states "I have had Jan in several intimate classes and can assure you that her attendance record is exemplary. Yours very truly, etc." Here the professor has flouted the maxim of quantity, for lie knows that more information is desired. In the context of a letter of recommendation, it is expected that a professor will communicate as much positive information as possible. The omission of certain expected sorts of information can ouly lead to the inference that in those areas the professor is

66. See generally Grice, supra note 63. Grice uses the noun implicature and the verb implicate instead of the less precise but more natural implication and imply.

67. Id. at 45 . 
unimpressed. ${ }^{68}$

\section{Implication in the Bargaining Context}

There are many ways in which particular words can imply offer or acceptance in a conmercial setting. $A$ might offer $B$ a certain suin of money to work in $A$ 's office, and $B$ 1might smiply reply, "I look forward to working with you" or "When do I start?" Neither of these utterances has the direct illocutionary force of acceptance, but they inply in these circumstances the equivalent of "I hereby accept your offer."

Fairmount Glass Works v. Crunden-Martin Wooden Ware Co. ${ }^{69}$ is a case involving implied assent. The buyer wrote the seller asking for the lowest price on ten carloads of Mason green jars. The seller wrote back, "Replying to your favor of April 20th, we quote you Mason fruit jars ... Pints, \$4.50; quarts, $\$ 5.00$. . f for immediate acceptance."70 The buyer ordered ten carloads, which the seller refused to provide. Even though price quotations usually do not constitute offers, the court decided that the seller's reply was indeed a definite offer to sell.

Superficially, the seller did nothing more than respond to a request for information; the literal ineaning of the language gave no indication that there was a bargain between two parties. In a conımercial context, however, a request for a price presupposes some interest in buying. This implication was even stronger in Fairmount because the buyer specifically asked for the lowest price on a specific number of jars. The request was roughly equivalent to: (1) "We wish to buy ten carloads of Mason fruit jars"; (2) "What is your lowest price?" A relevant answer would speak to both issues. A seller who did not wish to sell would have answered, "No Mason fruit jars for sale," rebuffing the buyer's attempt to buy and rendering the question of price irrelevant. The seller, however, did not respond directly to the buyer's implicit request to purchase ten carloads of jars. Therefore, the buyer was justified in interpreting the

68. The example is a variation on one given by Grice, $i d$. at 52 , and is a typical case of damning with faimt praise. Even the formal reporting of judicial cases uses such implication. When a judge concurs in the judgment, she literally does nothing different from the judges joining the majority opinion, who also concur in the judgment. On the surface, the judge violates the maxim of quantity when she states that she concurs "in the judgment." Rather than discarding the words "in the judgment" as unneeded information, the hearer will attempt to interpret them consistently with the maxim of quantity. The ntterance does not violate the maxim of quantity if in stating the extra information that it is the judgment with which she concnis, the judge implies that she disagrees with the rationale used in reaching the result.

This same conversational principle underlies the legal maxim of interpretation expressio unius est exclusio alterius ("the expression of one is the exclusion of the other"). If a set $A$ contains $x, y$, and $z$, then exphicit mention of $x$ in a statute by implication excludes $y$ and $z$. To mention $x$ and say nothing about the others would violate the inaxim of quantity by not being informative enough. The hearer rationalizes this potential violation of the inaxim by inferring that the otlsers are not included.

69. 106 Ky. 659, 51 S.W. 196 (1899).

70. Id. at 663,51 S.W. at 197. 
seller's price quotation as relevant to the implicit request and could infer that the seller was making an offer.

In the English case Harvey v. Facey, ${ }^{71}$ the buyer telegraphed the seller, asking, "Will you sell us Bumper Hall Pen? Telegraph lowest cash price." The seller responded, "Lowest price for Bumper Hall Pen $£ 900 . " 72$ The buyer then accepted what it considered to be an offer to sell. These facts parallel Fairmount, except that the purchaser's desire to buy was explicit, rather than implied. The court nevertheless concluded that the seller's response was not an offer because the seller had failed to answer the question regarding whether it would sell Bumper Hall Pen. It is perhaps dangerous to impose an anachronistic imterpretation upon facts which occurred almost a century ago and which may have turned upon particular trade conventions. But if such an interchange took place today, the seller's response would probably be viewed as an offer.

It is useful to consider the proper response had the seller not intended to make an offer. The seller should then have made clear that its response addressed only the question of price, and that it was preserving its options regarding a possible sale. If the seller did not wish to sell under any circumstances, it should have said so explicitly or not have answered at all. There are two logical interpretations of the seller's silence on the question of whether it wished to sell: (1) the seller did not answer the question; or (2) the seller's quotation of a lowest acceptable price imphed an offer to sell. Grice's cooperative principle states that if one bothers to reply at all, the response inust be relevant to the question posed. The seller's communication is relevant only if the price quotation is an actual offer.

Compare these cases to Owen $v$. Tunison, ${ }^{73}$ in which the buyer asked whether the seller would be willing to sell its store property for $\$ 6000$. The seller responded, "[I]t would not be possible for me to sell it unless I was to receive $\$ 16,000.00$ cash." 74 As in Harvey, the seller quoted a minimuin price which one assumes was higher than what he actually expected to receive. Yet in answer to the question regarding whether he would sell, he used the conditional phrases "it would" and "unless I was." This answer is ambiguous; the buyer either could have been implying that he would sell if he received $\$ 16,000$, or that he was uncertain that he would sell even at that price. Either response would be relevant to the question. The court's decision that this response was not an unequivocal offer was therefore justified, since it is not clear that by these

71. 1893 A.C. 552.

72. Id. at 555 .

73. 131 Me. 42,158 A. 926 (1932).

74. Id. at $43,158 \mathrm{~A}$. at 927. 
words the potential buyer was committing himself to the proposed bargain.

Soine courts have exphicitly refused to acknowledge that indirect acts can have the force of offer or acceptance. The seller in Nebraska Seed Co. v. Harsh" want $\$ 2.25$ per cwt. for this seed."76 Holding that this communication amounted to preliminary negotiations rather than an offer, the court explaimed that the seller "[did] not say I offer to sell to you."77 However, the lack of the formula "I offer to sell to you" is not the problein in this case. The real problein is the lack of the formula or equivalent language committing the seller to the proposed bargain. One indication that the seller's commumication does not have the force of an offer is the incomplete propositional content-there is no indication of how much seed is available. A businessinan probably would not coinmit himself to so nebulous a bargam. In addition, the supposed offer does not contain or miply the presence of a "you." Even if it were clear that the seller wanted to sell, it is not evident that the seller was committimg himself to a specific bargam with this particular buyer. ${ }^{78}$

These considerations are not definitive, but they do serve to make exphicit some of the ways in which native speakers reach conclusions as to whether parties have committed themselves to a proposed bargain.

75. $98 \mathrm{Neb} .89,152$ N.W. 310 (1915).

76. Id.

77. Id. at $91,152 \mathrm{~N} . \mathrm{W}$. at 311.

78. One way to better analyze a complex verbal interaction is to convert it into a conversational format in order to evaluate whether, according to the rules of ordinary language, agreement has been reached. For example, notice how the following hypothetical interchange obviously violates commonly accepted rules of conversation. $A$ enters a store and asks a clerk how much the teddy bear costs. The clerk replies that it costs $\$ 20$. $A$ produces $\$ 20$, whereupon the clerk replies that it is not for sale. This interchange shows that the clerk's reply that the teddy bear is not for sale (equivalent to a potential breach of contract) is not a legitimate ending to this dialogue, at least for the average hearer.

In more formal terms, we might analyze this dialogue as follows. $A$ 's request regarding the price of the teddy bear is simply that: a request regarding the price. It does establish a bargaining context, however, especially since the exchange takes place in a store. The clerk's answer that the teddy bear costs $\$ 20$ is an offer. This is a store, and there is an expectation that the merchandise is for sale. If it is not, stating a price is inappropriate as a violation of the maxim of quantity. A's production of the money is an acceptance of the offer. The clerk's "completion of this dialogue" by saying that the teddy bear is not for sale is "strange" in the ears of a native speaker, showing that a speaker of English assumes that an offer to sell the teddy bear for $\$ 20$ had been made.

We can paraphrase the Fairmount case, supra note 69 and accompanying text, which is similar to the above scenario, in the following way:

Buyer: "What's your lowest price for ten carloads of Mason green jars?"

Seller: " $\$ 4.50$ for quarts, $\$ 5$ for pints, available for immediate delivery."

Buyer: "I'll take ten carloads."

Seller: "They're not for sale."

The dialogue cannot be completed in this way, as the court recognized by holding that the seller had entered into and then breached the agreement. 
What is important is to realize that these indirect ways of expressing offer and acceptance inay communicate the saine inessage as the inore explicit "I hereby offer you that $p$ " formula. The crucial question is whether the parties, by their words or deeds, have in fact committed theniselves. To the extent that the law is concerned with enforcing actual commitments of the parties, it will have to interpret the language and the actions of the parties in the same manner that the parties themselves interpret them.

\section{$\mathrm{V}$ \\ ACTION AND INACTION}

A further problem of interpretation imvolves speech acts that are accomphished not by words, but by actions or conduct. For example, waving can perform the speech act of greeting, nodding the head may signify agreeinent, and certain hand signals in baseball signal that a player is out. All of these actions are conventional, with a fairly exphicit meaning which can be put into words. A particular thumb signal by an uinpire can be expressed by the words "I hereby judge you to be out."

When an action has no predetermined ineaning, it is often still possible to infer a meaning from the nature of the action in the surrounding circumstances. For example, if someone asks a boy to trim some bushes tomorrow, he might assent by nodding his head, a conventional symbol which is equivalent to "yes" in inost European cultures. Now suppose that he responds to the same question by inaking cutting inotions in the air with his shears. Though this action is not a conventional symbol for assent, one might interpret it as a promise. A similar analysis is possible where the neighbor boy, in response to the speaker's question and in his presence, begins to trim the bushes. One might also infer that this action functions as an agreement to complete the task. Of course, if lie begins performance in such a way that the offeror would remaim unaware of it, the action of beginning performance is not communication. Rather, in that case he is probably doing nothing more than beginning the task. He does not necessarily promise to complete it. ${ }^{79}$

When actions of this sort are meant to communicate, they can be

79. Grice, in his famous paper on meaning, discusses similar examples. If Fred Astaire puts on a tailcoat, one might infer that he is going to a dance. But Mr. Astaire does not necessarily communicate this intention. Of course, if one asks someone what he plans to do this evening and he flamboyantly puts on his tailcoat iu response, he could probably be said to have communicated something. In Grice's terms, when one infers something from an act which was not intended to communicate anything, the inferred meaning is natural. The natural meaning of smoke is that there is a fire nearby. But smoke signals, which normally indicate an intent to communicate, have nonnatural meaning (Grice's meaning-nn). Grice, Meaning, 66 PHIL. REV. 377 (1957). In a legal context, soineone who simply begins performance does not signal (does not mean-nn) assent. Thus no promise can be inferred. But someone who begins performance in such a way that the offeror will surely see him at work is communicating assent. 
speech acts and require the same elements as do verbal communications. Most important is the essential rule, which requires that the utterance or act must count as obligatimg the actor to carry out the proposed bargain. In spoken utterances an explicit performative or equivalent utterance serves this purpose. When the act is performed by acts or inaction, the force of the act is indicated in a different manner. Nevertheless, the necessary eleinents remain the saine. As with indirect verbal assent, the interpretation of action and inaction involves determining when an act is the equivalent of, or expressible as, an exphicit performative formula.

\section{A. Conduct as Assent}

It is well established in the law of contracts that conduct or action can signify assent to a bargain. ${ }^{80}$ When closing a bargain, shaking hands is a strongly conventionalized and unainbiguous way of comnitting oneself to the contract. Signing the document containing the terms of a bargain carries inuch the saine effect. In an auction, hand siguals inay function as an offer to buy, and pounding the gavel indicates acceptance.

More difficult questions occur where the conduct in question does not conventionally sigual assent. For example, in Nissen v. StovallWilcoxen $\mathrm{Co}^{81}$ the court held that an agreement signed by only one party but physically accepted by the other bound both. Thus, physically accepting an agreement which is signed (hence offered) by the other party inay perform the speech act of acceptance, even though receiving a signed piece of paper does not conventionally siguify assent to its terins. Rather, the circumstances of the case-physically accepting a signed document which was the result of bargaining-sustained an inference that the offer was being accepted.

The circuinstances allow a similar inference when someone buys computer software packets with an agreement concerning copying of the software visible through the wrapping. A typical agreeinent states, "Opeming this package indicates that you accept this agreement and will abide by it. If you don't agree with what it says, proinptly return the package unopened and your money will be refunded."82 The circum-

80. Restatement (Second) of Contracts $\$ 4$ (1979); Cal. Civ. Code $§ 1621$ (West 1973); see also RESTATEMENT (SECOND) OF CONTRACTS $\$ 19$. Section 19 of the Restatement is a curious amalgam of three parts. The first states the familiar rule of law that assent may be manifested by words, by action, or by failure to act. The second part states that the conduct of a party is not effective as a manifestation of assent unless he intends to engage in the conduet and knows or has reason to know that the other party may infer from his conduct that he assents. The third states that the conduct of a party may indicate that he assents even though he does not in fact assent. Perhaps a better formulation would be the simple statement that conduct can constitute assent when the conduct communicates to the other a commitment by the actor to the proposed bargain.

81. 120 Cal. App. 2d 316, 261 P.2d 10 (1953).

82. MicroPro End User Program License Agreement, September, 1982. While there seems to 
stances in this case give significance to an action which otherwise has no special meaning.

Conduct, no less than other types of offer and acceptance, inust count as committing the actor to the other person that he will perform the bargain. Generally it can be assumed that it is the person doing the action who is committing himself to the proposal, and therefore the "I" condition is fulfilled. That the nonverbal speech act is addressed to a "you" is often more difficult to determine. The action must be one that the other person can normally be expected to see for it to satisfy this second condition.

In White v. Corlies ${ }^{83}$ the defendants offered the plaintiff a job doing some repair work in their office. The plaintiff bought some wood and began preliminary work at his own place of business, without the knowledge of the defendants. The defendants countermanded the following day. Holding that a mental resolution to accept was inadequate, the court decided that the plaintiff had not accepted. Although the plaintiff had committed himself to the project in his own eyes, he had not coinmitted himself to the defendants.

While it is soinetimes assumed that one can only accept by conduct, it is possible to extend an offer by conduct as well. For example, a person might see apples in a box marked "twenty-five cents each" at a inarket where he has an account. He chooses one and holds it up for the clerk to see. The clerk nods, and the customer proceeds on his way. By his actions, the customer has offered to pay twenty-five cents for the apple, a proposal accepted by the clerk's nod. ${ }^{84}$

\section{B. Assent by Silence or Inaction}

In soine circumstances, silence or inaction can also constitute speech acts. ${ }^{85}$ During a meeting, the chairperson might state that all those who

be no reason not to view the act of opening the package as acceptance, there are problems of another kind. A particular user might not be aware of the "offer" and could hence not be held to have accepted by opeming the package. Without the peculiar circumstances-knowing that breaking the seal will be deemed assent-opening the package means no more than that the buyer wants to use the contents.

83. 46 N.Y. 467 (1871).

84. REstatement (SECOND) OF CONTRACTS § 4, illustration 2 (1979).

85. The Restatement declares that when an offeree fails to reply to an offer, his silence and inaction operate as acceptance in the following cases only:

(a) Where an offeree takes the benefit of offered services with reasonable opportunity to reject them and reason to know that they were offered with the expectation of compensation.

(b) Where the offeror has stated or given the offeree reason to understand that assent may be manifested by silence or inaction and that the offeree by remaining silent and inactive intends to accept the offer.

(c) Where because of previous dealings or otherwise, it is reasonable that the offeree should notify the offeror if he does not intend to accept. 
are not in favor of a inotion should raise their hands. Because motions must pass by majority approval, those who did not raise their hands may, depending on the applicable rules, have approved it. Similarly, the President of the Uirited States must sign proposed legislation for it to become law. After ten days, inaction by the President constitutes approval of the law. ${ }^{86}$

This Comment will refer to speech acts performed by silence or maction as "passive speech acts." The requirements for offer and acceptance apply here as well. One of the conditions on offers is the preparatory rule that states that the parties must deal with one another in good faith. ${ }^{87}$ The offeror must beheve that the hearer is willimg to accept the speaker's proposed promise in exchange for the promise or act that the speaker requests in return. This condition is quite important in cases of assent by maction. One cannot normally bind a stranger with the message, "I will assume that you will promise to accompany me to the theater unless I hear from you by Friday." Nor can one send a book to a stranger with a bill for ten dollars. On the other hand, once a book club and a customer have made an arrangement, inaction with respect to a notice about a forthcoming book constitutes acceptance. ${ }^{88}$

Leaving aside cases such as the book club example-where a previously negotiated contract states that inaction equals acceptance-the appropriateness of a passive speech act is closely tied to expectation. When a negative answer is expected, it can be signified by inaction. A positive response in the same situation requires an overt act. Inaction can signify a positive response only when it is expected that the answer will be "yes," an overt act then being needed to negate the positive expectation.

A somewhat banal illustration of such expectations is the addition of milk to tea. In inost parts of the United States, someone who orders tea is expected to want it without milk. Therefore, silence communicates the negative- "I want no milk." Yet in other parts of the world this expectation is reversed. In England silence communicates the positive-"I want milk in my tea." This reflects a general primciple of conversation:

Id. $\S 69(1)$.

Note that this nowhere mentions that an offer can also be made by silence or inaction. Yet, at least in theory, there is no reason why an offer could not be made in this way as well, given the proper circumstances. This concern may seem a trivial one, but it highlights the way in which speech acts-whether made by words, acts, or inaction-are alike, rather than concentrating on the differences.

86. U.S. CoNST. art. I, $\S 7$. This is true unless Congress has recessed. The presumption that inaction constitutes approval perhaps is less reasonable during a recess, when a "forgotten" bill might "accidentally" become law. Another possibility is that notice of acceptance is more problematic during a recess.

87. See supra note 32 and accompanying text.

88. RESTATEMENT (SECOND) OF CONTRACTS $§ 69(c)$ (1979). 
the obvious need not be stated. ${ }^{89}$

In a legal context, inaction can constitute the speech act of acceptance or offer only if there is an expectation that inaction serves as a positive response to a request for commitment. In a neutral situation, the expectation is that lack of response commuiricates a negative. Only where this expectation is reversed can there be acceptance by inaction. One way to reverse the expectation is by contract, as is the inethod of operation of soine book clubs. More often, previous dealings between the parties or the way in which particular business is typically transacted (conventions of the trade) can reverse this expectation. ${ }^{90}$

As with other types of assent, an acceptance by inaction must be calculated to reach the offeror. In other words, the inaction inust be "addressed to" and "reach" the party to whoin the commitment is being inade, the "you." This means that the offeror must be in a situation to know that the offeree has been inactive and is thereby accepting. The offeror cannot presume acceptance by inaction if there is a commurications strike at the time and the offeree could not have sent word to the offeror that she did not wish to accept.

A well known case of acceptance by inaction is Cole-McIntyreNorfleet Co. v. Holloway. ${ }^{91}$ A traveling salesman of the defendant went to the country store of the plaintiff and received an order for fifty barrels of ineal. This order had to be accepted at the office of the defendant wholesaler. When two inonths later the plaintiff was at the defendant's place of business, he was finally told that his offer to buy had been rejected. The Supreme Court of Tennessee held that the defendant had accepted by silence. ${ }^{92}$

In this case, one can assume that a large volume of orders was being sent by salesinen to the defendant. The convemient way to do business

89. Language itself offers a similar illustration. In traditional English usage a person of unknown sex is generally assumed to be male. This is especially evident in the rules regarding use of pronouns. Traditional grammar requires that tlie male pronoun be utilized in sentences such as "Someone seems to have left his book on the table" or "A lawyer should never neglect his clients."

When no mention is made of the gender of the lolder of an occupation, it is also typically assumed that the person is male. The phrases "male doctor" or "male law professor" sound unusual in our society. On the otlier liand, there is nothing strange in speaking of a "female doctor" or "female law professor," since unfortunately people continue to expect that doctors and law professors are males. There is in language a general principle that, where something is expected, it need not be specifically stated.

These expectations can be reversed in some contexts, however, just as the expectation that silence is rejection can be reversed in some circumstances. When speaking of some oceupations, the assumption is that the holder is female. One therefore does not refer to a "female secretary" or a "female nurse." For this reason, one would likely speak of a man in one of these positions as a "male nurse" or "male secretary."

90. See supra note 85 .

91. 141 Tenn. 679, 214 S.W. 817 (1919).

92. Id. at 683,214 S.W. at 818 . 
would have been to notify retailers only when rejecting an order. Absent an explicit rejection, the buyer could reasonably have expected that his order was being accepted. The frequent visits by the salesinan guaranteed that the inaction "reaclied" the buyer.

Anotlier difficult question in assent by inaction is when the inaction becoines a speecl act. If in Cole only one or two days had passed, then maction could not lave been given much weight. Depending on the normal flow of communications between the parties, after the next visit of the salesman the silence would have ambiguous. With each passing visit, there would have been a stronger inference that the inaction constituted acceptance.

Finally, it is often assuned that maction can constitute only acceptance, not an offer. Since offer and acceptance share inany traits as speech acts, lowever, it should be possible not only to accept, but also to offer by inaction. While unlikely for practical reasons, such cases are conceivable. An msurance company may send a letter to an insured stating that, unless it hears otherwise, it will assunie that the insured wants to renew ler policy. Inaction by the policyholder might then be treated as an offer. Similarly, an employer and employee miglit liave a monthly employment contract. The course of performance, or the explicit contract terms, might provide that each montli the contractor offers employment for another month, and the employee accepts, via inaction. ${ }^{93} \mathrm{~A}$ montl-to-montl lease generally operates on the same principle. Notice that im each of these cases, it is expected that the activity will go on for an indefinite period.

Inaction as a means of assenting to the terms of a bargain is thus not as different from other speech acts as might at first appear. It must be possible under the circunistances to interpret the silence or inaction as performing the act of offering or accepting. The action or inaction must therefore be the equivalent of a formula that commits the speaker to the hearer.

\section{Concluding Remarks on Interpretation}

Despite the variety of ways in which offer and acceptance can be achieved, the ultimate question is whether each party has committed itself to the other to carry out a proposed bargain. The conditions for a successful act of commitment to a bargain are fairly uniform. What may vary is the means by which the commitment is made. The crucial distinction does not lie in the traditional question of whether assent occurs by words (express) or by conduct (implied). ${ }^{94}$ Rather, a more useful dis-

93. 1 S. WILLISTON, supra note $21, \S 90$.

94. Cal. Civ. CoDe $\S \S 1620-21$ (West 1973). 
tinction depends on whether the commitment is made in an exphicit, conventionalized manner. The words "I hereby accept your offer" make that commitment quite transparent, but equally unambiguous is the pounding of the gavel at an auction. On the other hand, the words "Don't let that worry you" or the beginning of performance are much less exphicit acceptances and so require more careful scrutimy.

The Restatement says that "[c]onduct may often convey as clearly as words a promise or an assent to a proposed bargain."95 Yet the Restatement and the traditional typology both fail to note that the converse is also true-words may often be as ambiguous as conduct in conveying the force of a speech act. At times, an utterance may be so inherently ambiguous that only further communication can clarify the speaker's meaning. Yet im many other instances, context or the external circumstances may make it possible to arrive at the correct meaning.

Where the force of an utterance is not exphicitly rendered by the literal language of a sentence or by an act that has a strongly conventional meaning, assent may be expressed by phrases that have an idiomatic sense different from their word-for-word meaning, or by means of inference. ${ }^{96}$ In the former, an utterance that hiterally has another illocutionary force may be used idiomatically to indicate assent. In such cases, it may be necessary to eliminate competing meanings in order to interpret the utterance as assent. With implication, on the other hand, assent is to be found neither in the literal nor $\mathrm{m}$ the idiomatic meaning and must therefore be inferred from the context. ${ }^{97}$ Obviously, these processes

95. RESTATEMENT (SECOND) OF CONTRACTS § 19 comment a (1979).

96. S. LeVINSON, PRAGMatics 268-72 (1983), distinguishes between two theories that attempt to explain less explicit speech acts. The idiom theory, as the name suggests, treats them as idioms. "Can you pass the salt" under this view is an idiom which means "Please pass the salt." The other theory is what Levinson calls the inference theory. Adherents of this approach hold that "Can you pass the salt" is basically a question. A hearer infers its indirect meaning via Gricean notions of conversational impheature, see supra notes 63-66 and accompanying text, or a similar method. The hearer might react to this question by noting that it is obvious that he ean pass the salt. Assuming that the speaker is cooperating in the conversation, the hearer realizes that the literal meaning cannot be appropriate. Since the speaker is not able to reach the salt himself, the speaker must be requesting the hearer to pass the salt. In both of these cases, Grice's maxims of conversation make explicit how native speakers use the outside world to determine what an utterance means.

This Comment assumes that both the idion and the inference theories have some validity. A more refined analysis of the inference process is contained in J. Searle, supra note 60 , at 72-75; see also Morgan, Two Types of Convention in Indirect Speech Acts, in SyNTAX \& SEMANTIcs 9: Pragmatics 261 (P. Cole ed. 1978).

97. The Restatement suggests that "imply" should not be used for contracts which are inferred from facts. RESTATEMENT (SECOND) OF CONTRACTS $\S 19$ reporter's note comment a (1979). In reality, the distinction between inference and inplication is one of point of view-that which the speaker implies in words or deeds is what the hearer infers from those same words or deeds. See Morrison, I Imply What You Infer Unless You Are a Court: Reporter's Note to Restatement (Second) of Contracts $\$ 19$ (1980), 35 OKLA. L. REV. 707 (1982).

Courts often speak of terms liaving been implied when they were not implied by the parties at all. Courts speak this way when the parties would have included the terms had tley anticipated the 
are closely related. In fact, it will often be difficult to decide whether a specific example reffects a particular idiomatic meaning or conveys a meaning derived by inference.

Perhaps it is better to regard these two processes as extremes on a continuum. Idioms originate when a particular implication occurs so commonly that its meaning has become conventionalized. At first, the words "Don't worry about it" could function as a proumise only by implication in fairly specific circumstances. Now, however, a promise has for most people become a relatively conventionalized meaning of the phrase, almost to the exclusion of its original hiteral sense.

In all of these situations, the critical question is not how assent is indicated, but whether a person has performed an act that comnits him to carrying out a bargam. Whether there has been agreement depends on this act, not directly on whether the person truly nitends to carry out his promise. This does not suggest, however, that the mental state of the parties is irrelevant. It is the issue of intent that will now be considered.

\section{$\mathrm{VI}$ \\ INTENT}

Until now, this Comment has focused on the nature of the physical act by which people commit themselves to a bargam. The previous sections have elucidated some of the primciples which assist in determining when an act or utterance performs this function. This Part delves into the question of mental state in greater detail.

The role of mental state in contractual obligations has been the topic of soine debate, both in Europe and in the United States. Without attempting to deal exhaustively with the historical controversies, one can state that there are two possible extreme views. The first is that the law gives effect to agreeinents based on the intent of the participants. The inam problein with this subjective approach is that after agreenent has been reached, one of the parties might declare that it was never his intent

matter, or when the court imposes terms in the interest of justice. See generally Williams, Language and the Law-IV, 61 LAw Q. REv. 384, 400-404 (1945); RESTATEMENT (SECOND) OF CONTRACTS $\S 204$ comments a \& d (1979). It would be much more appropriate in these cases to refer to supplied terms, since the courts do not infer them from anything to which the parties directly or indirectly agreed.

Soinetimes the courts also deem assent to the terms of a bargain, as when goods are accidentally shipped to the wrong address and the recipient exercises dominion over them. Courts will enforce the terms of the contract despite the lack of assent. This might be called "supplied" or perhaps "deemed" assent. It should not be lumped together with cases where assent is truly implied by the words or deeds of the parties. Only in the case of truly implied assent is the contract based on agreement between the parties. Deemed assent, though it can give rise to expectation damages, is much more similar to quasi-contract. Id. $\S 69(2)$; Louisville Tin \& Stove Co. v. Lay, 251 Ky. 584, 65 S.W.2d 1002 (1933). 
to carry out the agreement or that the whole thing was a joke. ${ }^{98}$

The other possible extreme is that what matters is the expression of intent, or the apparent intent of the parties. Such an approach circumvents the problem of "hidden intent" or mental reservation, since only the intent that is expressed to the other party is relevant. At the same time, this objective approach introduces new difficulties. The greatest problem is mistake. Suppose that one person makes a written offer to sell her car for five hundred dollars, but that she imtended to write five thousand dollars. The objectivist would have to hold her to her expression, absent some ad hoc addition to the theory. ${ }^{99}$

This Comment approaches the question of mental state from the vantage poimt of speech act theory. ${ }^{100}$ Most of the debate regarding mental state seems to have centered on whether it is the intent or the expression of the intent that matters. Little attention has been paid to the types of intent which an actor can have, whether subjective or objective. It is that question which this Section will address. Assuming that the speaker or actor must at least intend to do the act or make the utterance, ${ }^{101}$ there are three remaining types of mental state that might be

98. Judge Jerome Frank advocated the subjectivist position in Ricketts v. Pennsylvania R.R. Co., 153 F.2d 757, 760-61 (2d Cir. 1946) ("The objectivists transferred from the field of torts that stubborn anti-subjectivist 'the reasonable man'"). In the ninetecnth century, the subjectivist position was strongly endorsed by many legal scholars in Germany. A strong advocate was Winscheid, who argued that the will was dominant over the expression of the will, at least if the will could be proven. In addition, declarations of the will made in error were invalid not because of the error, but because the purported obligation was not based on the will of the actor. B. WiNSCHEID, LEHRBUCH DES PANDEKTENRECHTS $179-80$ (3d ed. 1873). The debate between the German subjectivists and objectivists came to a head with the codification of the German Bürgerliches Gesetzbuch (Civil Code). The adherents of the will theory objected to the code section that stated that a secret mental reservation not to carry out the terms of the contract did not render the agreement void. They insisted (unsuccessfully) that if one party had a mental reservation, the minds of the parties could not have met. See 1 MÜNCHNER KOMMENTAR zUM BürgerLICHEN GESETZBUCH $\S 116$ Vorbemerkung II (F.J. Säcker ed. 1978).

99. Judge Learned Hand expressed the objectivist position quite forcefully:

A contract has, strictly speaking, nothing to do with the personal, or individual, intent of the parties. A contract is an obligation attached by the mere force of law to certain acts of the parties, usually words, which ordinarily accompany and represent a known intent. If, however, it were proved by twenty bishops that either party, when he used the words, intended something else than the usual meaning which the law imposes upon them, he would still be held, unless there were some mutual mistake, or something else of the sort. Of course, if it appear by words, or acts, of the parties, that they attribute a peculiar meaning to such words as they use in the contract, that meaning will prevail, but only by virtue of the other words, and not because of their unexpressed intent.

Hotchkiss v. National City Bank, 200 F. 287, 293 (S.D.N.Y. 1911), aff'd, 231 U.S. 50 (1913).

100. It is assumed here that certain classes of people are held to a lesser degree of responsibility for their actions. RESTATEMENT (SECOND) OF CONTRACTS $§ 12(2)$ (1979) (those with reduced capacity to contract include infants as well as those who are under guardians, mentally ill or defective, or intoxicated). Similarly, contracts made under coercion are not enforced. See, e.g., id. $\S \S 175-76$

101. An intent to do the act or make the utterance is almost universally regarded as a prerequisite to an offer or acceptance. See, e.g., 1 S. WILLISTON, supra note $21, \S 21$, at 39. 
essential to the social construct of agreement. One possibility is that the speaker must have certain positive thoughts and feelings regarding the bargain. Another is the related requirement that the speaker intend to carry out the proposal. While both of these are expected of soineone who performs speech acts of commitment, such as offer, acceptance, and promise, this Comment argues that neither is essential. It proposes mstead that these speech acts, to be effective, must be accompanied by what will be called illocutionary intent.

\section{A. Mental Assent}

The word "assent" is often used as a synonym of "accept," or else as a general term that covers both offering and accepting. Besides referring to these acts, it is also used to refer to a state of mimd. In this usage, it may connote positive thoughts or feelings regarding a proposed bargain. This definition appears to be miphicit in the Restatement (Second) of Contracts, which refers to an "agreement" as a "manifestation of mutual assent." 102 Because assent must be manifested, the language indicates that it is a mental state rather than an act. To distinguish the two, the state of mind will here be called mental assent. This tern will be used in reference to thoughts and feelings, but not to intent, which will be used to refer to the mental state that a person may have regarding the doing of a future act.

When a person declares "I hereby offer you that $p$," is it necessary that the person have positive thoughts and feelings about the deal? That an offer made in jest is valid, at least when the other is not aware of the joke, suggests that mental assent is not essential in our legal system. ${ }^{103} \mathrm{~A}$ contrary result would lead to the ridiculous conclusion that those who promise seriously are bound while permitting those who promise jokingly

102. Id. § 3. Similarly, the Restatement defines a promise as a "manifestation of intention ... so made as to justify a promisee in understanding that a commitment has been made." Id. $\S 2$ (1). A promise is better defined without reference to the "manifestation" of a mental state. Rather, a promise is an act by which a person commits hmiself to act or refrain froin acting in a specified way.

The Restatement's reliance on the terminology "manifestation of assent" and "manifestation of intention" has the further problem that there may be many manifestations of assent during the course of bargaining, while an offer or acceptance is made only once. From these many manifestations of assent, the Restatement elevates one above the rest as an offer. This leads to awkward formulations such as that in $\$ 26$, which specifies that a "manifestation of willingness to enter into a bargain is not an offer if the person to whom it is addressed knows or has reason to know that the person making it does not intend to conclude a bargain until he has made a further manifestation of assent." Id. $\S 26$. An offer might better be defined as an act which commits the speaker or actor to a proposed bargain, once it is validly accepted by the other party. Such a defintion properly characterizes these prior manifestations of assent as reports or indications of a mental state, not speech acts which commit the offeror to the proposal.

103. See infra text accompanying notes 111-12. In Roman law, use of the formula for stipulatio, for example, bound the speakers, despite a mental state to the contrary. M. KASER, supra note 3, at 44-45. 
to speculate at the expense of the other party. The unscrupulous could hold themselves to the promise if advantageous but plead lack of mental assent when the agreement becomes onerous.

Speech acts are generally effective regardless of whether a speaker has the requisite thoughts or feelings. Austin gives several examples. A person may say "I congratulate you" even though she is not at all pleased by your achievement, or "I'm sorry" when she has no real feelings of regret. ${ }^{104}$ Similarly, a judge may say "I find the defendant guilty" even though he behieves the opposite. The speech acts are effective in all of these cases: the speaker has congratulated, apologized, or found someone guilty despite the absence of appropriate feelings. There is no reason to assume that the speech acts of offer and acceptance operate any differently. ${ }^{105}$

\section{B. Sincerity}

Another mental state that may be relevant to whether agreement has been reached is sincerity, which here refers to the intent to carry out the terms of the proposal. Sincerity is quite intimately related to whether there is mental assent, simce absence of mental assent will generally imply a lack of intent to carry out the agreement. ${ }^{106}$

Just as with mental assent, a lack of imtent to carry out the proposal does not necessarily deprive a speech act of its force. The act of offering constitutes a commitment to carry out the proposed promise, if accepted by the other party. This commitment is the essence of an offer or acceptance. If sincerity were an element of an offer, an offer would commit the speaker to performing the proposal only when the speaker already intended to perform the proposal. Moreover, the notion of insincerity is meaningless in the absence of an act of commitment. The nature of insimcerity is that a person commits herself to something that she does not intend to do. If commitment depended on being sincere, no one could ever commit herself insincerely. ${ }^{107}$

104. J.L. AUSTIN, supra note 22, at 40.

105. A corollary to this conclusion is that mental assent is in itself insufficient to create agreement, as the following example from Williston shows. $C$ goes to $A$ and asks, "Are you willing to sell your horse to $B$ for $\$ 100$ ?" $A$ says yes, and $C$ goes to $B$ and asks if he is willing to buy the horse from $A$ for $\$ 100 . B$ agrees. Although there is mutual (mental) assent, no contract has been formed unless $C$ is an agent for one of the parties. In our terms, the essential speech act is missing, even though the intent may be clear. By itself, mental assent is not directly relevant to whether the parties have committed themselves to a bargain. I S. WILLISTON, supra note $21, \S 23$, at 52-53.

106. It is possible for a person to be sincere in, for example, accepting an offer without mentally assenting. This might occur where pending insolvency forees a person to accept a contract which he sincerely plans to perform, but the terms of which he finds very distasteful.

107. If an offer were merely an expression or manifestation of intent, someone who offered without intending to carry out the bargain would not be called insincere. He sinply would have lied about his intent. 
Sincerity is an eleinent of an offer only to the extent that the offeror ought to be sincere in the inoral sense, but it is not an essential condition for an offer. Suppose that Jones promises to repair the window of Smith's house, which had been broken by Jones's son. Suppose further that after soine timie, Jones has failed to perform, telling Smith that when he said "I promise" he did not intend to carry it out. Certainly no one would suggest that this absence of intention, if true, absolves Jones from his inoral obligation to Smith. Jones has violated the sincerity rule by promising while not intending to perform, but he has promised nonetheless. Searle's distinction between those rules which regulate and those which constitute a speech act is relevant here. ${ }^{108}$ Intending to carry out the proposal is a regulative rule but is not a constitutive rule of the speech acts of offering, accepting, or promising.

This view has miportant ramifications for the problein of reservatio mentalis, or mental reservation, which so plagued adherents of the subjective approach. ${ }^{109}$ The problem arises when one of the parties to a contract makes a seemingly valid offer or acceptance but secretly does not intend to carry out its terms. If legal obligation were based on the subjective intent to do the act, then there would be no contract. The injustice of such a position is manifest, but consistency demanded it of the subjectivists.

In the analysis presented here, the successful utterance of the speech act of offering commits the speaker, on acceptance, to carrying out the proposed bargain. That is the very nature of an offer or a promise. Though expected of the offeror, an intent to carry out the terms is not essential, since the proper inaking of a contract consists ipso facto of a commitinent to carry out the promised act. It is this act of commitment that the law enforces.

\section{Illocutionary Intent}

The previous section argued that mental assent and intent to carry out the terms of a bargain are not essential to an offer or acceptance. Although an offeror ought to be sincere, a lack of sincerity does not necessarily render the offer invalid. There is, however, a mental state which is essential. Speech act theory requires that an utterance or conduct be intended to produce in the hearer the illocutionary effect of offer or acceptance. ${ }^{110}$ What this means is that the speaker inust intend to make

108. See supra note 32 and accompanying text.

109. See supra note 98 and accompanying text.

110. As Searle puts it in regard to promise, "[t] $]$ he speaker intends to produce a certain illocutionary effect by means of getting the hearer to recognize his intention to produce that effect, and he also imtends this rccognition to be achieved in virtue of the fact that the meaning of the item he utters conventionally associates it with producing that effect." J. SEARLE, supra note 22, at 60-61. 
the hearer recognize or believe that in uttering words that count as an offer, the speaker is committing himself to the proposed bargain.

Because saying the words "I hereby offer" or the equivalent counts as committing the speaker to the proposed act, the speaker will usually intend to do that which his utterance predicates. It is the unusual cases which provide difficulties and which are therefore the inost interesting testing ground for this approacli.

Coinpare the following two cases. In one, the offeror jokingly proposes to sell his farm to anotlier. He knows that the offeree wants to buy the farm, and the offeror gives every indication that he seriously intends to sell. Unbeknownst to the offeree, lowever, the proposal is a practical joke. In the second case, an actor offers to sell his farm to another on stage. Both cases involve words that can obligate the speaker. And in both cases the speakers do not intend to carry out that obligation. Yet the law would probably find an offer only in the first instance.

The difference between these two apparent offers inust lie in the intent to create an illocutionary effect in the hearer. The joker is bound not because of inental assent, but because of an intention to fool the offeree into thinking tliat a commitment is being inade. Indeed, the whole point of the practical joke, where the otlier party is ignorant of the joke, is to inake the innocent party believe that a commitinent is being inade-tliat the offer is genuine.

On the other hand, when the speech act takes place on stage, there is no atteinpt to create in the hearer the illocutionary effect of an offer. Thus the stage offer seeins on the surface to have the illocutionary force of an offer but lacks the intent to inake the liearer think that the speaker is coinmitting himself.

Other situations illustrate that intent to create the proper illocutionary effect is distinct froin inental assent. Soineone miglit abhor the terins of a bargain but still accept them, hoping to carry out the contract if the price of a commodity goes up while planning to breach if it reinains the saine. There might be an element of insincerity or bad faith in such an acceptance, but it functions as an acceptance nonetheless because of the speaker's intent to create in the other party the perception that slie intends to be bound.

\section{Perspective}

The inental state that inust accompany an offer or acceptance is an intent to create a particular illocutionary effect in the hearer. The question is thus not simply whether the speaker intends to commit himself nor, as is soinetimes said, whether the speaker intends to be bound. The speaker's intent inust be measured by what the speaker intends to inake the hearer think that the speaker intends. 
Examining the speaker's intent in this fashion may at first seem somewhat convoluted. However, the value of this approach can be seen by comparing two cases of a joking offer. In one case, $A$ inakes a joking offer to sell his farm to $B$ for $\$ 10,000$. The price is reasonable and $A$ knows that $B$ would buy the farn at that price. In the other case, the price for the same farn is one million dollars, and $B$ is an unemployed city shicker.

From the poimt of view of the speaker, both offers are a joke. The only distinction between them is in how the speaker intends the hearer to perceive his intent. In the former case, the speaker wants to create in the hearer the impression that he intends to commit himself to the bargain. He knows that the hearer will interpret the offer as sincere, which is the purpose of the practical joke. This approach holds that if the joker, by means of his utterance, intends to inake the other believe that he is committing himself, the joker has indeed made an offer. If the joker does not want to make an offer, he must quickly expose the jest. Indeed, people in these situations normally feel compelled to inform the other alınost immediately that a joke was intended. The likely explanation for this behavior is that the joker realizes that he has made a commitinent and inust act quickly to undo it. In contrast, where the speaker knows that the hearer is aware that the price is absurdly high and that the hearer would not want to buy the farm anyway, there is probably no intent to create in the hearer the impression that the speaker intends to commit himself.

The case law largely supports the results of this analysis. A practical joke constitutes an offer where the other is not aware of the joker's intent. ${ }^{111}$ But where an apparent offer is obviously a joke from the perspective of the hearer, no offer has been made. ${ }^{112}$

This approach to intent sheds light on the problein of sincerity. One of the rules regarding inaking an offer is that the speaker ought to be smcere. At the same time, what constitutes an offer is that the speaker

111. See, e.g., Lucy v. Zehmer, 196 Va. 493, 84 S.E.2d 516 (1954).

112. See Keller v. Holderman, 11 Mich. 248 (1863); 1 WILLISTON, supra note 21, § 21, at 41. In Higgins v. Lessig, 49 Ill. App. 459 (1893), a harness worth fifteen dollars had been stolen. The owner said in rough language, punctuated with epithets, that he would give $\$ 100$ to the person who would find out who the thief was and would pay $\$ 100$ to a lawyer to prosecute him. Id. at 460 . The court held that these utterances were the extravagant exclamations of an excited man, and that the plaintiff had no right to consider them an offer. Id. at 461 . Note that the meaning of the language clearly indicates the force of ("counts as") an offer, but that the hearer would assume from the circumstances that the man did not have the intent to create in his hearers the illocutionary effect of an offer.

Obvious jokes do not commit the speaker in German law. The Civil Code states that a declaration of the will that is not seriously intended is void if made in the expectation that it will be understood not to be seriously intended. BGB $\S 118$. This formulation essentially states the requirement of illocutionary intent. 
commit himself to performing the promise, not that he sincerely intends to perform. Admittedly, this formulation may seem to suggest that the sincerity rule is largely irrelevant.

Yet the sincerity rule, as well as the other regulative rules of offering, take on greater significance in view of the requireinent that the speaker intend to create in the hearer the impression that he intends to commit himself. It makes no sense to say "I promise to sell you my bicycle but do not intend to sell it to you." The reason is not that it is impossible to promise insincerely-one can say to a third party, "I promised to sell her iny bicycle but I never intended to do it." Rather, this is not a promise because one caumot intend to cause the hearer to believe that he is committing himself while at the same time informing the hearer that he is not committing himself. When there is obvious insincerity - as opposed to hidden or secret insincerity-the speaker normally does not intend to create the requisite illocutionary effect. ${ }^{113}$ Thus where insincerity invalidates an offer, it is not because of the insincerity itself, but because someone who makes it obvious that he does not intend to carry out a proposal cannot have illocutionary intent.

\section{Ambiguity and Mistake}

Until now it has been assumed that illocutionary intent refers to an actual (subjective) intent of the speaker. Of course, the law imglit for practical reasons decide to ineasure illocutionary intent based on the perception of the reasonable hearer. In other words, the law might hold the speaker to the intent that the utterance normally would convey under the circumstances. ${ }^{114}$ In that case, the law might hold someone to terms of a bargain to which he did not intend to commit himself. Measuring intent from the point of view of the reasonable hearer circumvents soine evidentiary problems, but it favors the reliance interest of the hearer over the speaker's interest in being bound only when the parties truly have reached agreeinent.

Under this approach, there is less need to avoid referring to the actual intent of the speaker and focus instead on how the reasonable hearer perceives that intent. Many of the concerns of the objectivists, such as jokes and inental reservation, are far less problematic when intent is inore precisely defined as illocutionary intent. Under this approach, lack of sincerity and change of heart are not legitimate defenses to reaching agreeinent.

There appear to be only two situations in which the speaker can

113. This is expressed in the law by the rule that a clear intent not to be bound will be honored. See E. Farnsworth, Contracts $\$ 3.7$ (1983).

114. See, e.g., Corbin, Offer and Acceptance, and Some of the Resulting Legal Relations, 26 YALE L.J. 169, 205 (1917). 
make a legitimate argument that his subjective illocutionary intent should prevail over his objective intent as perceived by a reasonable person in the position of the hearer. The first occurs where the speech act is ambiguous. Suppose that a speaker says "I can fix your fence for five dollars." Under the circumstances, the most reasonable interpretation is that this is an offer. But suppose further that the speaker can show that his actual illocutionary intent was to create in the hearer the belief that he was making a price estimate. It would seem that the speaker has not committed himself and should not be bound to an offer. Even Williston, a strong objectivist, suggested that subjective imtent may be relevant in cases of ambiguity. ${ }^{115}$

The other situation where illocutionary imtent legitimately may differ froin objectively manifested intent is in cases of mistake. If the offeree orders a telegram with the words "I do not accept your offer" and the telegrapher sends the message "I accept your offer," the offeror's illocutionary intent is quite different from what the reasonable recipient will beheve it to be. The law can, of course, deem the speaker to have accepted. But it is clear that the speaker has not, in the terms developed here, committed himself. The speaker did not intend, by means of the telegram, to cause the offeror to beheve that he was obhigating himself to the proposal. There may be reasons to protect the rehance interest of the recipient here, which is what an interpretation by the "reasonable hearer" generally accomphshes. However, these reasons do not justify the imposition of a full contractual obligation on someone who did not intend to make the other party beheve that he wished to obligate himself.

The approach developed here suggests that legal effects should inure to acts of commitment. There is a contract ouly when both parties, judged by social and linguistic norms of the kind described in this Comment, have committed themselves to a legally cognizable bargain. Where there is imscommumication or imistake, courts should use their equitable powers to arrive at a solution that is as fair as possible to both parties. ${ }^{116}$

115. Williston, Mutual Assent in the Formation of Contracts, 14 ILL. L. REv. 85, 91 (1919).

116. See, e.g., Whittier, The Restatement of Contracts and Mutual Assent, 17 CALIF. L. REV. 441, 441-42 (1929); see also Eisenberg, The Responsive Model of Contract Law, 36 STAN. L. REV. $1107,1118-20$ (1984).

If there is true ambiguity, where the illocutionary intent of the speaker differs from the hearer's most reasonable interpretation, the parties should divide any resultant loss, provided that either both parties or neither of them should have been able to recognize that the ambiguity existed. Where one party could more easily have avoided the ambiguity or mistake, that party should bear greater responsibility. For example, one party may make what seems in all respects an offer, with no other reasonable interpretation of her words and conduct. If she then convinces the court that she had a different illocutionary intent, she should probably nonetheless be responsible for the entirc resulting loss, perhaps the equivalent of expectation damages. This is not because the court should deem her to have committed herself, but rather because it was solely her careless choice of words that caused 
Mistake and ambiguity are very similar. In both situations something has gone awry in the process of communication, and, therefore, the actual intent of the speaker does not match the hearer's perception of the speaker's intent. The approach of this Comment presupposes successful communication and provides no solution to these problems.

This might at first seem a shortcoming of this approach. But on closer exammation, it is appropriate that a theory that focuses on the notion of agreennent not provide solutions to the problems of mistake and ambiguity. Because the existence of agreenent depends on mutual acts of commitment, a valid theory must systennatically distinguish true agreement fronı apparent or legally imphed agreement. The failing of a strong objectivist position is that it provides too many answers. By invoking the "reasonable man", it finds "agreement" where none exists. Miscommunication and mistake cannot be solved by reference to agreement, since in both cases the attempts to communicate have failed. On the other hand, a pure subjectivist approach is too weak, for it finds no agreeinent where one of the parties is secretly insincere or had a mental reservation, even though agreenent exists in such situations in the eyes of the speech community. An adequate approach to the question of intent must recognize this limitation and provide a solution to all and only those issues which it competently can address.

\section{CONCLUSION}

This Comment has shown that the law and the philosophy of language have similar concerns. The philosophy of language provides a useful approach for analyzing the language and actions used to commumicate offer and acceptance. The analysis presented here suggests that offer and acceptance are speech acts that must have a particular force-the force of committing the speaker to the proposal. There are several rules that regulate how that commitnent ought to be made, among them rules relating to good faith bargaining and sincerity. But what is essential is that there be an utterance or act that counts as committing the speaker to a proposal. This crucial elennent is most explicitly satisfied by the performative formulas "I hereby offer you" and "I hereby accept."

Often action, inaction, or less exphicit utterances will potentially indicate the force of offer or acceptance. Then it becomes necessary to determine whether the words or inaction are the equivalent of, or expressible as, the explicit performative phrases. In addition, the words or deeds must be accoinpanied by a particular mental state. Certain

the harm, including missed opportunities. These ideas draw on tort law, and it is in these caseswhere no agreement has been reached-that notions of fault are especially appropriate. See Eisenberg, supra, at 1120. 
types of inental state, such as mental assent or an intent to carry out the terms, are not necessary to create a bargain. What is crucial is that the speaker inust intend to create in the hearer the illocutionary effect of offer or acceptance by causing the hearer to recognize the speaker's intent to create that effect. In other words, the speaker must intend to create in the hearer the perception that the speaker wishes to commit herself.

While insincere and joking offers are often offers nonetheless, an obviously insincere or joking offer cannot be intended to create the requisite illocutionary effect, and it thus does not operate as an act of commitment. It is mainly in cases of anbiguity and mistake that subjective illocutionary intent and the hearer's interpretation of the speaker's intent are likely to diverge. Therefore, the subjective element is inost important in these areas. Though the speaker has not committed himself in such cases, he might be held responsible for the consequences of careless communication. But since the hearer plays a role in determining ineaning as well, she may also bear responsibility for inistake or ambiguity.

Many legal consequences arise from verbal acts or through a functionally equivalent physical act or inaction. This Coinment has attempted to provide a framework for showing that the various nodes of offer and acceptance inust all adhere to a single set of overriding principles. Similar principles apply, in large ineasure, to other speech acts that establish relationships between parties by means of communication. It is hoped that this study of the langnage of offer and acceptance will someday be part of a larger investigation of how language effects legal relations.

Peter Meijes Tiersma*

* B.A. 1974, Stanford University; Ph.D. 1980, University of California, San Diego; thirdyear student, Boalt Hall School of Law, University of California, Berkeley. 